\title{
Five Problems for the Moral Consensus about Sins (Penultimate Draft)
}

\author{
Mike Ashfield, University of Southern California \\ This is a preprint of an article published in InternationalJournalfor Philosophy of Religion. \\ The final authenticated version is available online at: https://doi.org/10.1007/s11153-021-09795-x.
}

\begin{abstract}
A number of Christian theologians and philosophers have been critical of overly moralizing approaches to the doctrine of sin, but nearly all Christian thinkers maintain that moral fault is necessary or sufficient for sin to obtain. Call this the "Moral Consensus." I begin by clarifying the relevance of impurities to the biblical cataloguing of sins. I then present four extensional problems for the Moral Consensus on sin, based on the biblical catalogue of sins: (1) moral overdemandingness, (2) agential unfairness, (3) moral repugnance, and (4) moral atrocity. Next, I survey several partial solutions to these problems, suggested by the recent philosophical literature. Then I evaluate two largely unexplored solutions: $(a)$ genuine sin dilemmas and $(b)$ defeasible sinfulness. I argue that $(a)$ creates more problems than it solves and that, while $(b)$ is wellmotivated and solves or eases each of the above problems, $(b)$ leaves many biblical ordinances about sin morally misleading, creating (5) a pedagogical problem of evil. I conclude by arguing that (5) places hefty explanatory burdens on those who would appeal to $(b)$ to resolve the four extensional problems discussed in this paper. So Christian thinkers may need to consider a more radical separation of sin and moral fault.
\end{abstract}

Keywords Sins • Moral Faults • Dilemmas • Defeasibility • Pedagogical Evil

Ingolf Dalferth (1984) distinguishes the ontological question 'what is sin?' from the criteriological question 'what is sinful?'. Much theological discourse on the doctrine of sin concerns the ontological question of sin's nature or essence, but recent philosophical discussions of sin have often grappled with the criteriological issue of which acts, attitudes, or states of affairs should count as sinful or fall under sin's extension, whatever sin turns out to be. In this paper, I identify problems that emerge from answers to the criteriological question of how sins are extensionally related to moral faults. My primary aim is to engage critically with recent relevant Englishspeaking philosophical scholarship, so I will not attempt an in-depth historical study of how theologians or philosophers have answered this question throughout the ages, and I will not address cognate theological topics, like soteriology. However, in setting up the problems I discuss, ${ }^{1}$ I will refer primarily to the Hebrew Bible and the New Testament, because these are the primary authoritative canons of texts informing the religious traditions, in which recent English-speaking philosophical discussion of sin has taken place, and because the Christian traditions and their roots in Jewish traditions are the ones I know best.

\section{The Moral Consensus about Sin's Extension}

There are five options for understanding the extensional relationship between one's target concepts of moral faults and sins:

${ }^{1}$ I rely on the New Revised Standard Version translation of the bible and employ Society of Biblical Literature abbreviations for biblical texts, though some quoted material contains other abbreviations. 
Sub-Moralism: sins are a proper subset of moral faults; all sins are moral faults, but not all moral faults are sins; moral fault is necessary for sin to obtain, but not sufficient;

Equi-Moralism: sins and moral faults are co-extensive; sins are moral faults and vice versa; moral fault is necessary and sufficient for sin to obtain;

Super-Moralism: moral faults are a proper subset of sins; all moral faults are sins, but not all sins are moral faults; moral fault is sufficient for sin to obtain, but not necessary;

Non-Moralism: sins and moral faults overlap; some sins are moral faults-some not; some moral faults are sins - some not; neither is necessary or sufficient for the other to obtain; and,

Anti-Moralism: sins and moral faults are disjoint; they are wholly distinct normative states of affairs; each is sufficient for the other's absence (see Dalferth 1984, 175).

Equi-Moralism seems to be the majority position among Christians. The Catholic Encyclopedia (O'Neil 1912) affirms Equi-Moralism from within the natural law tradition, declaring that sin is moral evil and sins are nothing other than morally bad acts. Likewise, on prominent voluntarist theories, sin and moral fault are co-extensive, as both are just whatever is contrary to God's will or commands. ${ }^{2}$ Thus, in the Blackwell Companion to Philosophy of Religion (2010) entry on "Sin and Original Sin," Philip Quinn affirms that "The concept of sin is the concept of a human fault that offends a morally perfect God and brings with it guilt" (614), before explaining how voluntarists and natural law theorists differ in their understand ings of sin's co-extension with moral fault. Equi-Moralism entails two weaker extensional claims:

Moral Necessity: moral fault is necessary for sin to obtain; and, Moral Sufficiency: moral fault is sufficient for sin to obtain.

(For convenience, I will sometimes refer to the proponents of these claims as "Moral Necessitarians" and "Moral Sufficientarians," respectively.) Unsurprisingly, this combination of commitments is often assumed in the background of related debates. ${ }^{3}$ However, in the 1980s and early 90s, a flurry of philosophical work on the relation between moral fault and Judeo-Christian conceptions of $\sin ^{4}$ reconsidered each of these Equi-Moralist commitments, picking up earlier lines of theological criticism.

Sub-Moralists retain Moral Necessity but reject Moral Sufficiency, arguing that while all sins are moral faults, some moral faults are not sins. This combination of commitments appears to be rare. ${ }^{5}$ But David Attfield (1984), following in an enlightenment-era liberal tradition associated with Pierre Bayle, ${ }^{6}$ has defended a Sub-Moralist account of the "mature" Christian concept of sinful acts. On Attfield's account, sin presupposes the moral, as sins are "acts contrary to morality"

\footnotetext{
2 For example, Quinn 1978, 136.

${ }^{3}$ For example, M. M. Adams 1988 and 1991 observe that it pervades a ssumptions about theodicy and the free will defense.

4 See Mitchell 1984, Dalferth 1984, Attfield 1984, R. M. Adams 1985, M. M. Adams 1991, and a book-length treatment in Kellenberger 1995. See also Kilcullen 1983 and Lewis 1983.

5 Dalferth, Attfield's co-symposiast on sin in Religious Studies 20 (2), observes that Sub-Moralism is not even contemplated by their lead symposiast, Basil Mitchell, "and for obvious reasons: it is difficult to see how it could be held" (177). Attfield cites Tennant 1912 as the basis for his analysis.

${ }^{6}$ See Kilcullen 1983 and Bayle 1686-1687.
} 
(237), but "sinful acts" is the narrower category, because it includes only conscious, voluntary, blameworthy offences that are objectively against God.

Super-Moralists, in contrast, retain Moral Sufficiency while rejecting Moral Necessity, arguing that while all moral faults are sins, some sins are not moral faults. This combination of commitments seems to have been espoused by several prominent theologians. For example, Emil Brunner writes: "It is perfectly possible to combine being a sinner with being "good" in the ethical sense; indeed, in the last resort the fact of being or not being a sinner has nothing to do with the difference between the morally "good" and the morally "evil"" $(1957 ; 1939,154) .{ }^{7}$ Other probable Super-Moralists include Richard Niebuhr (1935), Reinhold Niebuhr (1943), Gerardus van der Leeuw (1938), and Rudolf Otto (1958). ${ }^{8}$

Accordingly, a number of philosophers have defended Super-Moralist views. Under the influence of Brunner and Reinhold Niebuhr, the young John Rawls (1942) defended a SuperMoralist position in his senior undergraduate thesis for the Princeton philosophy department. ${ }^{9}$ Basil Mitchell argued that while sin is manifested in moral wrongdoing, it is also manifested in "more impalpable failures of insight" (1984, 172-173). Dalferth similarly declared that "the fact of sin manifests itself unambiguously in moral wrongdoing and ambiguously in moral rightdoing" $(1984,188)$, but he rejected Mitchell's implicit assumption that 'sin' is univocal, adopting a SuperMoral account of sinful acts, and an aporetic stance toward the morality of original sinfulness. Robert Adams's (1985) position is less explicit, but he seems to have assumed Moral Sufficiency, while doubting Moral Necessity. And Marilyn Adams (1991) defended a hybrid of SuperMoralism and Anti-Moralism: at a secondary stipulative level, she argued that moral faults, states of ritual impurity, and certain kinds of thoughts, emotions, and habits - conscious or unconscious, voluntary or nonvoluntary - constitute statutory sins; but at a fundamental level, she argued that 'sin' signifies an "impropriety in the relation between created persons and God. The difficulty cannot be moral at bottom" (1991, 2, original emphasis). ${ }^{10}$ So a number of theologians and philosophers rejected Moral Necessity in the twentieth century, but these same were careful not to deny Moral Sufficiency.

In this century, Jesse Couenhoven (2009) has defended an account of sin based on Susan Wolf's notion of deep responsibility, which claims to be agnostic about sin's relationship to morality. However, Couenhoven's discussion tacitly assumes Moral Sufficiency, questioning only Moral Necessity. ${ }^{11}$ Leigh Vicens (2018) similarly sets aside issues of moral responsibility to argue that implicit bias constitutes sin, but should implicit bias constitute sin without morally responsible failure, this would represent a challenge to Moral Necessity alone. Erin Roberts (2014) treats Moral Necessity about the English meaning of 'sin' as one of her principal foils, ${ }^{12}$ in advocating

\footnotetext{
${ }^{7}$ Brunner thinks one can be morally faultless and yet sin in being self-righteous about one's moral faultlessness (154 155); K. P. R. Niebuhr (1943, I.212) and Rawls (2002; 1942, 201-202) make nearly identicalarguments.

${ }^{8}$ See H. R. Niebuhr 1935, 275; van derLeeuw 1938, 517 and 527; K. P. R. Niebuhr 1943, I.212, and Otto 1958, IV.1 and VIII. For helpful discussion of H. R. Niebuhr, see Couenhoven 2009, 566, 568-569 (Couenhoven also cites K. P. R. Niebuhr). For helpful discussion of Otto, see Lewis 1983, 144-145 (Lewis also cites van der Leeuw) and especially M. M. Adams 1991,3-7.

9 Rawls 2002; 1942,201-202.

${ }^{10}$ van der Leeuw 1938 and Otto 1958 each defend hybrid Anti-/Super-Moral accounts, cited approvingly by Lewis 1983 .

${ }^{11}$ Couenhoven professes a gnosticism, but questions only Moral Necessity in discussing sin's limits (573-574).

12 Roberts argues that "Paul's use of hamartia and its cognates in 1 Cor aligns neither with the modern [Sub-Moralist] understanding that $\sin$ is a willful offense a ga inst God that often comes with soteriological consequences nor with the [Anti-Mora list] idea that sin is a congenital angst that bears itself out a s the kind of guilt that only Christ can fix" (361; cf. 346).
} 
greater flexibility in biblical translation of the Greek term. ${ }^{13}$ And, for his argumentative purposes, Mark Schroeder (2020) assumes the disjunction of Moral Necessity or Moral Sufficiency. ${ }^{14}$

To the best of my knowledge, no one has defended a purely Anti-Moral view. Søren Kierkegaard (1849) and Dietrich Bonhoeffer (1949) may be Non-Moralists, but this remains unclear. ${ }^{15}$ Thus, despite substantive disputes among Equi-Moralists and their critics about what sin and morality are, a larger extensional consensus around the disjunction of Moral Necessity or Moral Sufficiency persists, and I will refer to this as the "Moral Consensus." Every member of this Moral Consensus defends or assumes some very close extensional relationship between sin and moral fault: all sins are moral faults, all moral faults are sins, or all the above.

Figure 1: Proposed Extensional Relationships between Moral Faults and Sins

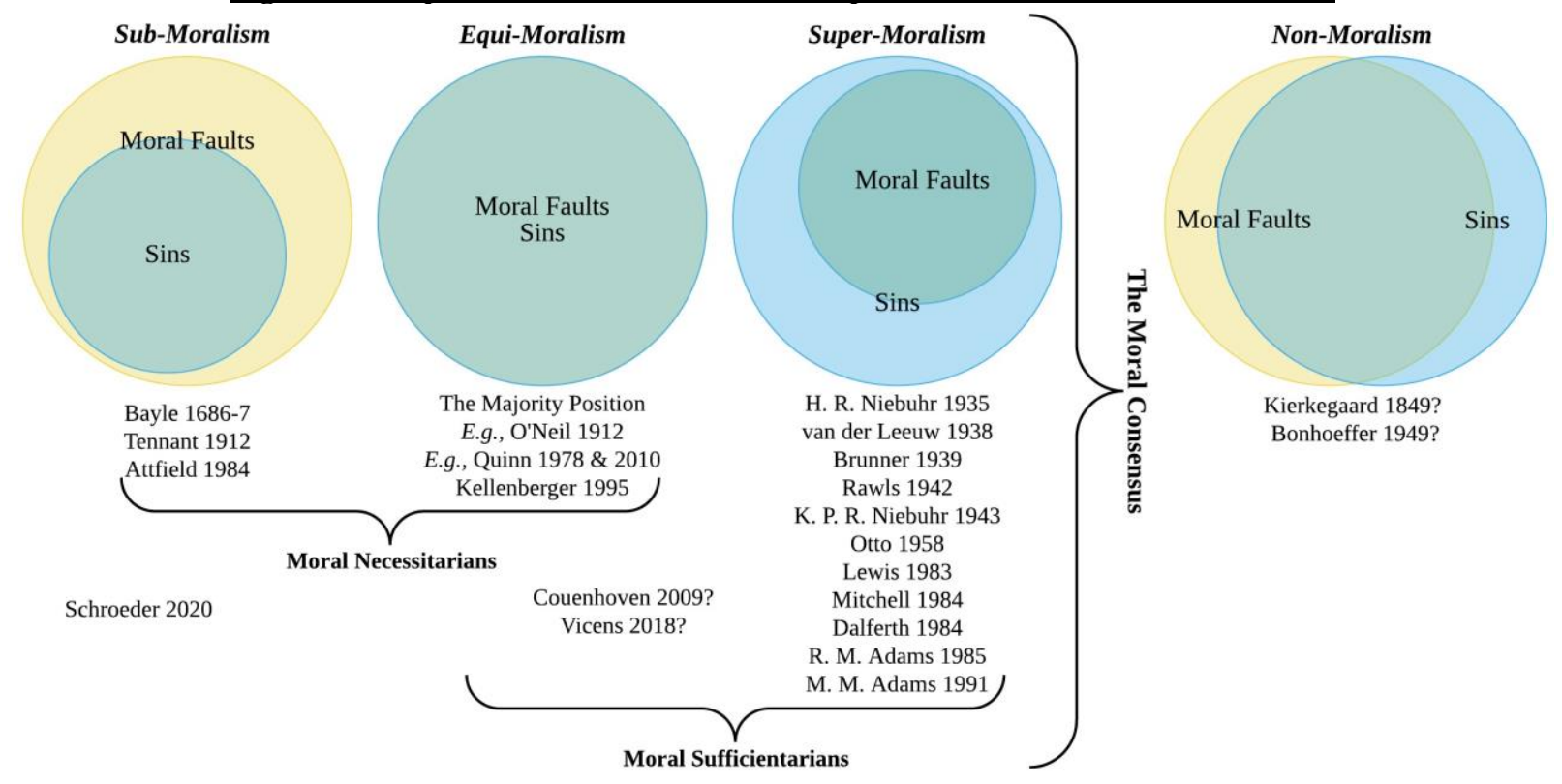

In what follows, I begin by clarifying the relevance of impurities to the biblical catalogue of sins. I then present four problems for maintaining Moral Necessity or Moral Sufficiency about this biblical catalogue of sins: the problems of (1) moral over-demandingness, (2) agential unfairness, (3) moral repugnance, and (4) moral atrocity. Next, I survey some partial solutions, suggested in the philosophical literature surveyed above. I then consider two largely unexplored general solutions that are available to all members of the Moral Consensus: $(a)$ the existence of genuine hamartiological (i.e., sin) dilemmas; and $(b)$ the defeasibility of pro tanto sinfulness. I show that, while much can be said for both solutions, $(a)$ creates more problems than it solves; $(b)$ seems well-motivated and solves or eases each of the above problems, so it is clearly an attractive solution. But $(b)$ also leaves many biblical ord inances about sin deeply misleading with respect to morality and God's will, creating (5) a pedagogical problem of evil. So anyone appealing to $(b)$ owes us an explanation for why God has allowed such enduring and consequential moral misguidance in scripture. Parties to the Moral Consensus must further explain how this is compatible with their commitment(s) to Moral Necessity or Moral Sufficiency. Thus, hefty

\footnotetext{
$13 \dot{\alpha} \mu \alpha \rho \tau i ́ \alpha$ (hamartia); see Strong's Greek entry 266; $c f$. dictionary entries for its classical Greek predecessors here.

${ }^{14}$ Schroeder affirms neutrality between Equi-Moralism, Super-Moralism, and Sub-Mora lism (3).

15 See Coady 2012 and Kirkpatrick 2013. Dalferth articulates the Non-Moralist option most clearly, but he dismisses it a s (gnostic) heresy $(1984,182)$.
} 
explanatory burdens await those who appeal to sin's defeasibility to resolve the four extensional problems identified in this paper. So Christian thinkers may need to consider a more radical separation of sin and moral fault.

\section{Cataloguing Sins in the Bible: Do Impurities Count?}

From the perspectives of most Christian communities and believers, the biblical catalogue of sins does not by itself settle the question of what is sinful. Still, Couenhoven (2009) rightly observes that, other things being equal, the more a view of sin can accommodate and make sense of scriptural data together with other Christian speech and practices concerning sin, the more attractive it will be, and even sophisticated Christian epistemologies of sin must contend with the biblical data, ${ }^{16}$ so I will focus there. Before I proceed, however, I must say a little bit about how the normative categories of impurity and sin are extensionally related. As this is itself a vexed question, my aim here is to survey the extant scholarly positions, because, as I will explain in the next section, none of these scholarly views presents an obstacle or solution to the problems I enumerate there in section 3.

Marilyn Adams (1991) argues that sin fundamentally is uncleanness, and some scholars have claimed that impurity is equated with sin in the Hebrew Bible, ${ }^{17}$ Second Temple Judaism, ${ }^{18}$ New Testament. ${ }^{19}$ But most specialists in this area seem to think that the only ancient precedent for equating the two derives from the Jewish Sectarians at Qumran, known through the Dead Sea Scrolls. ${ }^{20}$ Adams is especially indebted to Otto and the early work of anthropologist Mary Douglas, ${ }^{21}$ but she is also influenced by Mitchell, all of whom favor the inclusion of some unclean, impure, or defiled states in the catalogue of sins. Still, the extent of their inclusion is disputed. ${ }^{22}$

Scholars often distinguish between different kinds of impurity. The characterization of this distinction remains contested, but most seem to agree that the Hebrew Bible addresses at least two kinds of defilement. "Ritual impurity" concerns biological and often unavoidable sources of pollution, while "moral impurity" is caused by certain sins. The Hebrew Bible juxtaposes these two conceptions, without ever explaining their interrelationship, so the question of their relationship has been answered differently by different groups of Jews (Klawans 2000). ${ }^{23}$

\footnotetext{
16 See especially Dalferth 1984, 183-184 and Morriston 2012, 128-134.

${ }^{17}$ For examples, Moore 1919,42 and Buchanan 1970, 159-160.

${ }^{18}$ For example, Gavin 1928,9.

${ }^{19}$ For examples, Neyrey 1986, 98 and 101; Borg 1987, 86-87 and 1994, 109; Rhoads 1992, 149; and Ma lina 1993, 154-157; cf. Klawans 2000,12, 144, 167 nn. 54-56, and 211 n. 65.

${ }^{20}$ Neusner 1973, 54; Newton 1985, 10-51; García Martínez 1995, 139-57; Klawans 2000, 75-91, Kazen 2010, 207208; Werrett 2012, 515; cf. Harrington 1993, Himmelfarb 1999, and Holtz 2012. Haber 2008, I.3, summarizes the foregoing debate.

${ }^{21}$ In light of criticism, Douglas later retracted many of her early conclusions about "the Abominations of Leviticus;" see Douglas 2002, xiii-xvi; Haber 2008, 13 n. 21.

22 My thanks to an anonymous referee at Religious Studies for pressing this objection to a previous version of this paper.

${ }^{23}$ Concerns for ritual purity are broadly understood to reflect a Priestly textualtradition incorpora ted within the Torah (including Lev 1-7 and 11-15; see Nihan 2012,313); moral purity is associated with a later textual tradition in the Torah, known as the Holiness Code. In place of "ritual," some prefer "bodily," "physical," "levitical," "cultic," "priestly," or "ceremonial" impurity. In place of "moral," some prefer "spiritual" impurity. The latter is caused by certa in "sins," "offenses," and "unethical" or "wrongful" acts. In a ddition to those listed above in footnote 20, scholars who favor such a distinction include Hoffman 1905,303-304; Büchler 1928, ix; Frymer-Kensky 1983, 399; Maccoby 1999, 202-203; Regev 2004, 385; Hayes 2007, 746-749; Konkel2012, 452; Nihan 2012, 338; and Raushe 2012, 467468. In the tea chings of Jesus, Kazen 2010 argues it becomes a matter of “outer" vs. "inner” purity; see 222. Klawans
} 
Thomas Kazen (2010) identifies two candidate "systems" of ritual purity and a third system associated with moral purity:

1) The classification of animals into clean and unclean, i.e. edible and non-edible (Lev 11). This legislation gives no sanctions in case of transgression, nor does it envisage any means of purification, but assumes that the rules are always followed.

2) The system of bodily transferable impurity (Lev 12-15; Num 19) ... This legislation provides both sanctions and purification rites, and descriptions about how impurity is transferred as well as instructions on how to avoid contamination, since it assumes that people at times become impure, either by necessity or accident.

3) Laws concerning grave sins which were regarded as polluting: certain sexual sins and idolatry, particularly child sacrifice (Lev 18-20), as well as murder (Num 35). Sexual sins and child sacrifice render the persons involved impure (Lev 18:24). All three grave sins are seen as making mainly the land (Lev 18:25), and in the case of child sacrifice even the temple (Lev 20:3) impure, with the result that the land will vomit the people out, i.e. exile them. No purification is envisaged, but in the case of murder the land can be atoned for only by vengeance (Num 35:33) (203-204).

However, Kazen argues these "systems" actually overlap to such a degree that the material does not conform neatly to the above categories (2010), and scholars like Jacob Milgrom (1976) and David Wright (1991) have instead systematized a spectrum of defilements from the minor and ceremonial (or "tolerated") to the serious and sinful (or "prohibited"). ${ }^{24}$ I will enumerate some of the most morally problematic elements of these systems in section 3, but before I do, let us consider an argument for maintaining a clean distinction between impurities and sins.

\subsection{Separating (Ritual) Impurities From Sins}

Jacob Neusner (1973) and Hyam Maccoby (1999) accept categories approximate to those above, affirming the authenticity of ritual impurity, but following the second century rabbinic tradition of the Mishnah, each is critical of a genuine defilement caused by sins. Neusner accepts that the acts defined in Leviticus 18-20 are sins and moral failures, but he argues they are only metaphorically defiling (1973). Maccoby draws an even harder distinction between ritual purity and ethics, ${ }^{25}$ which he says is "characteristic of Judaism at all periods" (205)—Qumran apparently notwithstanding. He insists that ritual impurity is not sinful, and he denies that sin is ever genuinely

says Hoffman's seminal work in this area was informed "by talmudic and medieval rabbinic literature. But more important, Hoffmann and the medieval Jewish exegetes were preceded by Philo and the early rabbinic sages (the tannaim), who very clearly distinguished between ritual, bodily impurities on the one hand, and the defilement that results from sin on the other" $(2000,6)$.

${ }^{24}$ See also Newton 1985, 2-4; Frevel 2012,376-377; Nihan 2012, 339-350; and Rausche 2012,468-473.

25 Maccoby distinguishes between rules binding only on Jews (lex judaica) and rules binding on all of humanity (lex gentium), which he insists is basic in biblical and rabbinic Judaism: "[ritual] elements are intended to be subordinate and limited; they are not a coded philosophy, but just what they purport to be, rules for the conduct of a priestly society [applying only to Jews, converts, and residents of the Holy Land], in which a sense of constant attendance on God demands a protocol which in no way supersedes the demands of ordinary [moral] duties to neighbours, family and strangers" (1999, 195). 
defiling. ${ }^{26}$ But he too accepts that the elements of sexual morality and other ethical concerns enshrined in Leviticus 18-20 are "the same for all human beings, Canaanites as well as Israelites" (203), and he never denies the sinfulness of the offenses defined by this "moral" system. So while there is some precedent for keeping dietary uncleanness and bodily impurities out of the catalogue of biblical sins, no one seems to deny that "moral impurities" are sinful in the Hebrew Bible.

\subsection{Impurity in the New Testament}

What did important figures in the New Testament have to say about impurity? The evidence concerning Jesus' attitude toward purity is complex, ${ }^{27}$ disputed, and difficult to summarize, ${ }^{28}$ but the central pieces of textual evidence from Mark 7 and Mat thew 15 attribute to Jesus "the id ea that attention to moral purity is more important than attention to ritual purity. That is, Jesus here is addressing himself to the relationship between ritual purity and moral purity, and clearly he prioritizes moral purity over ritual purity. [...but...] For Jesus, a discussion of ritual impurity ledinevitably perhaps?-into a discussion of sin" (Klawans 2000, 149). So while Jesus seems to have prioritized matters of sin and moral purity, he also did not clearly separate those concerns from matters of ritual purity. ${ }^{29}$

The author of the Epistle to the Hebrews thinks the need to maintain ritual purity ended with Jesus' death, though enduring lessons are drawn from an analogy between ritual and moral impurity (Heb 9:9-14). Klawans suggests that Paul's position bears some resemblance to this: "Like John [the Baptist], Paul views baptism as a ritual of atonement that effects purification from moral defilement. Like Jesus, Paul's interest in defilement is focused on moral impurity. ... [but] he does not articulate any interest in issues relating to ritual impurity. So with Paul we see a break with the past, in his rejection of the need to maintain ritual purity" $(2000,156) .{ }^{30}$ However, Christine Hayes (2002) has argued that Paul's ideas concerning purity are innovative and difficult to describe in terms of moral and ritual impurity, suggesting a third category of "carnal" impurity, which Moshe Blidstein (2017) summarizes as being "caused by intentional sin and not some

${ }^{26}$ See Maccoby 1999,200-201,208; see a lso Konkel 2012 on Ezek 40-48.

27 As Klawans says, in introducing the question of Jesus' relationship to the Law:

Matthew's Jesus declares unambiguously, toward the beginning of the Sermon on the Mount, that "not one letter, not one stroke of a letter, will pass from the law until all is accomplished" (Matt. 5:18). On the other hand, Mark would have us understand that Jesus declared all foods pure (Mark $7: 19 \mathrm{~b}$ ), thus abrogating the food laws of Leviticus 11 and Deuteronomy 14. As we will see, Mark $7: 19 \mathrm{~b}$ is widely recognized to be a secondary gloss. And the Sermon on the Mount contains all sorts of adaptations, interpretations, and other modifications of the law that Matthew's Jesus claims to have fully upheld (2000,143; see 146-150).

${ }^{28}$ See Kazen 2010 for a book-length treatment of this question.

${ }^{29}$ Klawans arrives at similar conclusions about John the Baptist's views on purity:

John insisted that in order to atone for sin, one had to undergo a baptism - a rite whose practice ancient Jews were more likely to associate with ritual purification ... [So] he clearly did not compartmentalize ritual impurity and $\sin$. But because he did not apparently view sin as a source of ritual defilement, he did not merge the conceptions of ritual impurity and sin. As far as we can tell, John did not consider sinners to be ritually defiling and thus probably did not conceive of his baptism as purificatory in the ritual sense. ... [So it seems] that John's baptism worked as a ritual of moral purification, effecting atonement by purifying individuals from moral defilement $(2000,143)$.

John appears to have been primarily concerned with sin and moral impurity, but what evidence we have suggests he did not completely divorce those concerns from matters of ritual purity.

${ }^{30}$ See also Newton 1985, 97. 
unintended contagion, but nevertheless functions through the physical, individual body, is transmitted from flesh to flesh, and is purified through a once-in-a-lifetime bodily ritual, baptism" (154). ${ }^{31}$

The evidence of the New Testament, therefore, is mixed. Yet, even if Christians think that, on balance, this evidence weighs in favor of ritual impurities being (or having been at one time) sinful, it seems that they also have good reason to think they are properly regarded as being (or having been) less sinful. Moral impurity, on the other hand, remains a grave matter throughout the New Testament, wherein the catalogues of defiling sins ascribed to Jesus suggest considerable overlap with earlier lists, despite some significant changes and expansions (Klawans 2000; Blid stein 2017; Mark 7:20-23; and Matt 15:18-20), while Paul generally reserves the language of impurity for sexual sins (Newton 1985; Klawans 2000; Blidstein 2017; Rom 6:19; 1 Cor 5:11-13, 6:15-19; 2 Cor 12:21; Gal 5:19; Eph 4:19, 5:3-5; Col 3:5; and 1 Thess 4:3-6.).

All of these extensional models, therefore, count at least some impurities (or so-called "impurities") as sins, and this ensures that none of the above presents an obstacle or solution to any of the problems I enumerate in the next section.

Figure 2: Proposed Extensional Relationships between Impurities and Sins
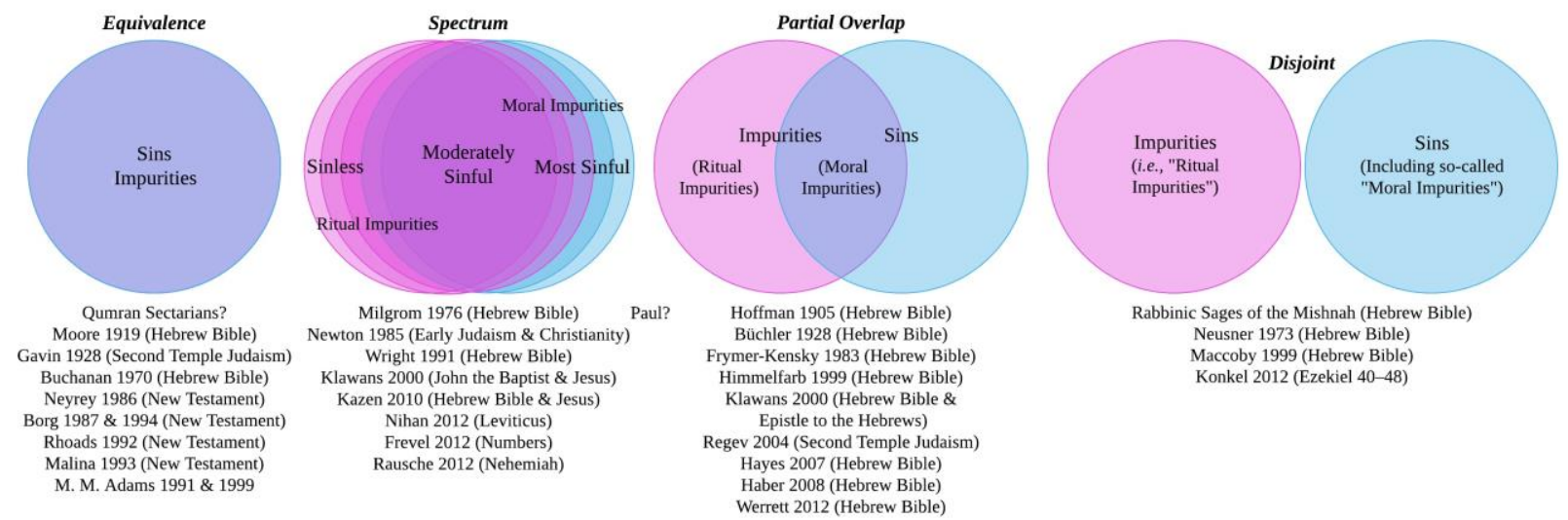

\section{Four Extensional Problems for the Moral Consensus about Sins}

Consider Marilyn Adams's summary of biblical sins:

the Biblical catalog of sins includes, not only (i) conscious voluntary actions, but also (ii) emotions (e.g., anger) and cognitive states (e.g., belief) not within our (direct) voluntary control, (iii) dispositions, habits, inclinations that resist the normative ordering of the self, and (iv) states or conditions of uncleanness (e.g., the abominations of Leviticus) (1991, 2).

Four extensional problems arise from elements across all four of these categories of sin, with some problems arising for elements from more than one category. Several of these problematic elements will be familiar to those well-versed in the problems of evil, but my aim here is to show that they also pose extensional problems for the Moral Consensus about sins. These problems obtain for all parties to the Moral Consensus, regardless of how they understand the nature of sin or moral fault.

31 See also Hayes 2002,96 and 254 nn. 16, 17. 


\subsection{The Problem of Moral Over-Demandingness}

With respect to (i) conscious voluntary sins, Jesus is reported to have taught that God requires the performance of intuitively supererogatory self-sacrificial acts, like turning the other cheek to an aggressor who strikes you, or loving your enemies (Matt 5:38-48). If conscious, voluntary nonobservance of these requirements is sinful, then Moral Necessity will have significant revisionary implications for most prominent normative ethical theories. Specifically, it enlarges the extension of what is morally impermissible to include inactions (i.e., refraining from supererogation) ordinarily thought permissible. If harshly sanctioning such omissions ${ }^{32}$ is sinless, then (by contraposition) Moral Sufficiency entails that such harsh sanctions are morally permissible. Either of these changes would make one's normative ethics implausibly demanding, so call this the problem of moral over-demandingness.

\subsection{The Problems of Agential Unfairness and Moral Repugnance}

In relation to (ii), some cognitive states, especially the element of unbelief in an agent's lack of religious faith, are said to constitute sin. Most explicitly, the author of Hebrews writes: "Take care, brothers and sisters, that none of you may have an evil, unbelieving heart that turns away from the living God" (Heb 3:12; see 3:19; 4:3), warning especially against unbelief born of hardheartedness (Heb 3:8-16; 4:7). The moralist might assume that the relevant cognitive state, or doxastic process whereby it obtains, is voluntaristic and sinful only when willfully irrational. ${ }^{33}$ But repeated warnings against deception suggest that the state itself is sinful, even if rationally held, formed in response to misleading evidence, or not directly within one's voluntary control. ${ }^{34}$ After all, God "has mercy on whomever he chooses, and he hardens the heart of whomever he chooses" (Rom 9:18), and most Christian believe that without repentance this sin of unbelief receives eternal punishment in hell. Yet, on most prominent normative ethical views, it is not clear that cognitive states, especially those beyond our control, constitute moral faults, ${ }^{35}$ so the revisionary implications of Moral Necessity extend even further.

Concerning (iii), Jesus also teaches that conative attitudes, like desires or intentions to commit adultery, are no less sinful than their objects, like the act of adultery itself. Jesus is reported to have taught that "everyone who looks at a woman with lust has already committed adultery with her in his heart" (Matt 5:28). In the preceding pericope, ${ }^{36}$ Jesus says there is no difference, in terms of one's liability to judgment, between the act of murder and the kind of anger exemplified in insulting someone, and as he later explains, such evil intentions, which proceed from the heart, are among the sins that defile a person (Matt 15:18-20; Mark 7:20-23). Similarly, 1 John 3:15 explicitly equates hatred with murder: "All who hate a brother or sister are murd erers." It is widely accepted that attitudes can express immoral dispositions, or reflect badly on one's moral character, but Jesus seems to take the stronger position of equating the sinfulness of conative attitudes with the sinfulness of the desired or intended act. On most prominent normative ethical views, it is not

\footnotetext{
32 See e.g., Matt 7:15-23; 13:24-30,36-43;25:41-46.

${ }^{33}$ Cf. Job $21: 14$.

${ }^{34}$ See Mark 13:5-6; Matt 24:4-5; Luke 21:8; Eph 5:6; Col 2:8; 2 Thess 2:3; 1 Tim 6:20-21.

35 However, for arguments that cognitive attitudes can be morally impermissible and can morally wrong others, see e.g., Basu 2018 and Basu and Schroeder 2019. For arguments that they can wrong God, see Schroeder 2020. For a defense of moral responsibility for, and the sinfulness of, certain nonvoluntary cognitive attitudes see R. M. Adams 1985.

${ }^{36}$ See Matt 5:21-22; see Jas 1:19-20.
} 
clear that conative attitudes - particularly those outside our direct or indirect voluntary controlconstitute moral faults at all, much less wrongings on a par with the desired or intended act. ${ }^{37}$

Finally, listed among the (iv) states of uncleanness are ritual impurities, which intuitively seem morally permissible. These include things like (unwittingly) touching the carcass of a pig, ${ }^{38}$ or perhaps wearing clothing of mixed fibers (Lev 19:19). Some conditions outside one's (direct) control are also considered ritually impure, like being acutely postpartum, being "leprous," or menstruating (Lev 12-14), and Aaronic priests with any physical "blemish," like blindness, dwarfism, physical disability, or disfigurement, are excluded from presenting food offerings in the Tabernacle (Lev 21). Though Neusner, Maccoby, and some others argue that ritual impurities were not sinful in themselves, ${ }^{39}$ failures, including unintentional or unknowing failures, to observe cultic requirements surrounding these ritual impurities, clearly constituted sin (Lipinski and Jacobs 2007; Hayes 2007; Lev 4-5) and were subject to punishment (Lev 5:17). So even on the most restrictive accounts, which exclude these impurities (or "impurities) from counting as sins, these ordinances still create problems.

Maintaining Moral Necessity about the sinfulness of voluntary (ii) cognitive, (iii) conative, and (iv) bodily states, further enlarges the extension of what is morally impermissible to include states ordinarily considered beyond moral evaluation, representing a prima facie challenge to the moral-'ought' implies 'can' principle (hereafter, "the M-OIC principle"). ${ }^{40}$ As the M-OIC principle reflects the idea that morality should make fair demands on our exercises of agency, call this the problem of agential unfairness. Independently, the implied immorality of some of the above nonvoluntary bodily states of impurity have misogynistic, xenophobic, and ableist implications for one's normative ethics, creating a distinct problem I will call the problem of moral repugnance. As we saw in the previous section, if sanctioning any or all of these defined offenses is sinless, then (by contraposition) Moral Sufficiency entails such sanctions are morally permissible, so versions of these two problems may arise for Moral Sufficientarians as well.

\subsection{The Problem of Moral Atrocity}

Admittedly, Moral Sufficiency's problems may appear less serious, especially since no specific sanctions are defined for some of the above offenses. But a more serious problem arises for maintaining Moral Necessity or Moral Sufficiency about the system of moral impurities, because they define intuitively non-moral offenses as grave sins and prescribe morally atrocious sanctions for the same. Here, I remind the reader that even under the Mishnaic division of ritual impurities from sins, the following offenses are still considered gravely sinful.

These statutes are depicted as having been designed by God to set Israel apart from its neighbors (Lev 18:3, 24; 20:22-24), keep citizens and aliens alike (Lev 18:26; 19:10; 20:2) from practices or states deemed defiling (Lev 18:20-30; 19:31; 20:3, 25), ${ }^{41}$ profane (Lev 18:21; 19:8, $11,29 ; 20: 3),{ }^{42}$ or abominable (Lev 18:22-30;19:7; 20:13, 25), ${ }^{43}$ preserve the land and its inhabitants from defilement (Lev 18:26-27; 19:10, 33-34; 20:2), and make Israel holy (Lev 19:1).

\footnotetext{
${ }^{37}$ For a defense of moral responsibility for, and the sinfulness of, certa in conative attitudes see R. M. Adams 1985.

${ }^{38}$ Lev 5:2; 11:1-8; Deut 14:1-8.

${ }^{39}$ Couenhoven concurs that leprosy, for example, was considered ritually impure but not sinful; see 2009, 565 and 576.

${ }^{40}$ For discussion see Kellenberger 1995, 305-309; see R. M. Adams 1985 for a partial response to this challenge.

${ }^{41}$ See Strong's Hebrew entry 2930.

42 See Strong's Hebrew entry 2490.

43 תוֹעָבַה (toebah); see Strong's Hebrew entry 8441.
} 
Leviticus 20 sets forth capital punishment by stoning ${ }^{44}$ for several offences defined in Leviticus 18-19, including cursing or dishonoring a parent, consensual adultery, bestiality, consensual homosexual sex, and specific narrowly-defined categories of incest, even singling out one of the latter offences for burning (Lev 20:14), though others are ignored. Leviticus 21:9 adds that a daughter of a priest who practices prostitution is also to be burned, because she thereby profanes her father (Lev 21:9). However, burning seems to have been used to aggravate the punishment of stoning during biblical times, with the corpse being burned after execution (Cohn, Rabinowitz, and Elon 2008, 445-446; see Josh 7:25). ${ }^{45}$ God also orders the stoning of a man in Numbers 15:3236 for gathering firewood on the Sabbath, an offence defined in Leviticus and elsewhere as a failure to keep the Sabbath holy (Exod 35:2-3; cf. Lev 19:3; 23:3; Exod 16:23; 20:8-10; 23:12; 31:14-17; Deut 5:12). Most disturbingly, God commands the Israelites to commit genocide during their conquest of Canaan:

"But as for the towns of these peoples that the Lord your God is giving you as an inheritance, you must not let anything that breathes remain alive. You shall annihilate them - the Hittites and the Amorites, the Canaanites and the Perizzites, the Hivites and the Jebusites - just as the Lord your God has commanded, so that they may not teach you to do all the abhorrent things that they do for their gods, and you thus sin against the Lord your God" (Deut 20:16-18; cf. Deut 7:1-11; 1 Sam 15:2-3).

The Hebrew word here for 'abhorrent things' 46 indicates motivations related to impurity, and as God says earlier: "Make no covenant with them and show them no mercy. ... break down their altars, smash their pillars, hew down their sacred poles, and burn their idols with fire. For you are a people holy to the Lord your God; the Lord your God has chosen you out of all the peoples on earth to be his people, his treasured possession" (Deut 7:2, 5-6).

These offenses are harshly sanctioned, because they are understood to be grave sins, and Moral Necessity entails that these acts are morally faulty. But any such normative ethical view is implausibly demanding and repugnant. Unfortunately, the problems do not end there, because the closing chapter of Leviticus strongly implies that failing to observe any of the ord inances contained in the book, including capital sanctions prescribed in Leviticus 20, is itself sinful (Lev 26: 14-39; cf. Deut 28:15-68). Moral Necessity about these additional sins of disobedience entails that failing to put people to death, for things like dishonoring their parents, is morally faulty or wrong, so putting them to death is morally obligatory. ${ }^{47}$ At the same time, if obeying these capital sanctions is sinless, and that seems like a safe assumption, then (by contraposition) Moral Sufficiency entails that these incredibly harsh sanctions can be enacted without moral fault. Moral Necessity thereby enlarges the extension of what is morally obligatory, and Moral Sufficiency the extension of what is morally permissible, to include heinous acts, making moral successes of misogynistic, homophobic, and xenophobic atrocities, among others, and turning normative ethics upside down. Call this the problem of moral atrocity. Such morally abhorrent implications can only be sustained

\footnotetext{
44 Stoning is thought to have been the standard method of judicial execution in Biblical times, but Talmudic jurists later developed a more humane substitute to stoning, by which the danger of mutilation was considerably reduced and death a ccelerated. See Cohn, Rabinowitz, and Elon 2008, 446; cf. Lev 24:23; Num 15:36; 1 Kgs 21:13; 2 Chr 24:21.

${ }^{45}$ In contrast, burning someone alive is reported as a non-Jewish Babylonian punishment in Dan 3:6.

46 תוֹעַבה (toebah); see footnote 43 above.

47 Given $\mathrm{K}(\diamond \equiv \neg \square \neg)$, if it is not permissible to not $\varphi(\neg \diamond \neg \varphi)$, because it is morally faulty or wrong to not $\varphi$, then $(\neg \square \neg \varphi$ ). Double-negation elimination yields $(\neg \square \neg \varphi \longrightarrow \neg \neg \varphi)$, and $(\square \neg \varphi \longrightarrow \neg \varphi$ ), so it is obligatory to $\varphi(\square \varphi)$.
} 
by sacrificing entirely the substance of God's alleged moral goodness, not to mention the plausibility of one's normative ethics.

\section{Partial Solutions in the Recent Philosophical Literature}

Prima facie, the Moral Consensus faces serious extensional problems, with Moral Necessity and Moral Sufficiency each creating their own versions of the problems of moral over-demand ingness, agential unfairness, moral repugnance, and moral atrocity, respectively. There are a number of ways to limit the scope of these problems, ${ }^{48}$ but in this section I will focus on solutions.

Michael Bergmann, Michael Murray, and Michael Rea identify three strategies for dealing with the Bible's morally problematic contents:

1. Reject God's Authorship: Deny that the text is divinely inspired;

2. Reinterpret God's Intent: Allow that the text is divinely inspired, but (i) deny that the apparently problematic commands and permissions therein were in fact the commands and permissions intended by God, and (ii) identify a morally unproblematic message as the overall divine message of the text; or

3. Recover God's Larger Moral Purpose: Allow that the text is divinely inspired and that the apparently problematic commands and permissions were in fact divinely intended, and argue that they are unproblematic because they serve a greater good, or impose just punishments for sin, or are in some other way consistent with God's duties toward human beings and with God's character as perfectly loving and morally perfect $(2011,7)$.

To this list, one might add:

4. Bite the Bullet: Accept that the texts are divinely inspired and that the apparently problematic commands and permissions were in fact divinely intended as is.

I think Christian thinkers can sensibly consider this fourth strategy in response to the problem of moral over-demandingness - especially with respect to the demands of self-sacrificial love - but I will assume without argument that simply Biting the Bullet in not an appropriate response to the problems of moral repugnance or atrocity. In general, different strategies may be appropriate for different problems, and we cannot canvass every version or combination of these four strategies,

\footnotetext{
${ }^{48}$ For example, Jesus says he is not abolishing even the least demand of the Law, "until all is accomplished" (Matt 5:17-18), suggesting that the sinfulness of (iv) ritual impurities could be abolished when Christ's High Priestly ministry is completed with his crucifixion (see Heb 1-10), fulfilling all requirements of holiness in the Law and freeing God's people from its constraints (see John 19:30; Acts 10; Rom 3; 7:6; Gal 3; Phil 3). Alternatively, or in addition, one might try to argue that the most draconian prohibitions related to moral impurity na rrowly address the idolatrous excesses of Israel's neighbors, which sometimes involved child sacrifice. On this proposal, these prohibitions were more specifically targeted at acts like consensualhomosexualacts of idol worship, and had no wider intended moral or social import (see e.g., Lein 2015). Meanwhile, the Jewish Sanhedrin decided its competence to inflict capital punishment ceased with the destruction of the Second Temple in $70 \mathrm{CE}$, because "at a time when there is no priest, there is no judgment of capitalcases" (Sanh. 52b, Ketub. 30a; $c f$. Sanh. 41a). And though Jewish courts continued to execute death sentences where they had the power, it is not clear that capital punishments for offenses of moral impurity continued to be enforced (see Cohn, Rabinowitz, and Elon 2008, 447). At best, however, each of these proposals only restricts the problems of moral repugnance or atrocity to smaller historical segments of the normative states of affairs - they do not solve the problems.
} 
but in this section I will survey some representative partial solutions suggested by the recent philosophical literature.

\subsection{Robert Adams's Defense of Moral Responsibility for Some Involuntary Sins}

Robert Adams (1985) defends an expanded scope for moral responsibility ${ }^{49}$ over nonvoluntary (ii) cognitive and (iii) conative states: "the thesis that we are ethically accountable only for our voluntary actions and omissions must be rejected. There are involuntary sins [i.e., involuntary acts, omissions, and states that are inherently blameworthy]." We need not examine his arguments in detail, but this is a narrow-scope version of the fourth strategy addressed at two of the more difficult aspects of the agential unfairness problem, and it looks to be one of the most promising partial solutions in the philosophical literature. Adams implies that sin has distinctly non-moral theological meanings, suggesting that he rejects Moral Necessity and avoids its problems. However, in assuming that ethical blameworthiness suffices for sin, he presupposes Moral Sufficiency, so one might naturally wonder whether his defense of involuntary sins has any implications for the Moral Sufficientarian's problems of agential unfairness and moral repugnance arising from the sinfulness of nonvoluntary (iv) bodily states of ritual impurity. But it appears that he would not defend moral responsibility for these nonvoluntary (iv) bodily states, ${ }^{50}$ so no further help can be gleaned from his position.

\subsection{Placing Morally Relative Limits on Sin with Attfield's Sub-Moralism}

Attfield's Sub-Moralism avoids extensional problems generated by Moral Sufficiency and lends itself to Rejecting God's Authorship of the texts causing problems for Moral Necessity, because his account is silent on all of the problematic categories of sin. Attfield locates the extension of the "mature" Christian concept of sinful acts within conscious, ${ }^{51}$ voluntary, blameworthy moral wrongs. He thinks the standards determining moral blameworthiness are socially constructed within liberal society. In private matters, where liberalism permits "a variable superstructure of individual id eals, espoused accord ing to choice, resting on top of a common social morality" (229), the relevant standards of wrongness are subjective, but their eligibility for individual selection is socially determined. But since "we have no independent knowledge in a disputable area for what

\footnotetext{
${ }^{49}$ See discussion of this tactic in Mitchell 1984, 167-173; Dalferth 1984, 179-181; Kellenberger 1995,302-307; and Couenhoven 2009, 567.

50 Adams contends that we are directly responsible for states of mind with intentional objects, "responding, consciously or unconsciously, to da ta that are rich enough to permit a fairly adequate ethicalappreciation of the sta te's intentionalobject and of the object's place in the fabric of personal relationship;" we a re not accountable for "simple feelings of hunger and thirst, insofar as they are primitive responses to physical stimuli" $(1985,26)$; nonvoluntary bodily states clearly resemble the latter more closely than the former. Elsewhere, however, Adams suggests that a divine command theorist might "theorize that the objectively disgusting is what disgusts God" (1987, 262), leaving room for impure states to have normative, if not ethical, significance. For recent arguments that cognitive attitudes can morally wrong others, see e.g., Basu 2018 and Basu and Schroeder 2019; for arguments that they can wrong God, see Schroeder 2020.

${ }^{51}$ Since the eighteenth century liberals have often placed a high value upon sincerity and a comparatively lower value on being right. Attfield's Sub-Moralism falls within this liberal tradition, but he acknowledges that in matters of fundamental social mora lity, like the wrongness of Nazism or genocide, we dare not recognize sincere "invincible ignorance" of moralstandards or egregious moral error as excuses from moralblame, in otherwise responsible agents. In this respect, Attfield departs from an earlier liberal tradition, associated with Pierre Bayle and some Jesuits, according to which there is no sin, properly speaking, unless we know that we are sinning, which implies that if the Nazi acts in accordance with their warped conscience they do not sin. See Attfield 1984, 234-235; Kilcullen 1983.
} 
is right and wrong and so are hesitant to speak of objective moral law ... with ethically debatable questions [e.g., abortion] we may just have to leave the issue undecided" (233). Attfield says that "objectively speaking," sins are offences against God, whether or not they are so understood by the offender, so the moral rules are not formulated under the assumption that God exists or is a moral patient. Indeed, many contemporary liberal societies deliberately eschew such assumptions. But his discussion suggests that the only sense in which this is settled "objectively" is that it is (mostly) settled by liberal social morality, and never by individual moral commitments alone. No recourse to objective moral facts is ever implied. Attfield thereby defends a liberal cultural relativism about the epistemology of moral blameworthiness, and perhaps the ontology of moral fault itself. Christian Miller (2018) summarizes the problems such a view faces in combination with theistic commitments:

Moral relativist positions ... are already fraught with numerous problems just on philosophical grounds. But from a theistic perspective they seem completely untenable. For it is hard to think that God would leave it up to individuals or cultures to decide whatever they like about moral matters. This is especially apparent when we turn to actual theistic religions. Time and again we see in the Bible and the Koran how God morally condemns human behavior on the basis of invoking a higher morality that clearly seems to have more authority than whatever the people in question are thinking (88).

Given Jesus's reported claim that "with the judgment you make you will be judged, and the measure you give will be the measure you get" (Matt 7:2), it would be unsurprising for the Christian God to apply human standards of moral judgment to determine (at least, in part) whether they are guilty of moral wrongd oing or sin. But Attfield's account leaves no room for any higher human-minds-independent divine standard, so while a realist or theistic constructivist SubMoralism could avoid this problem, Attfield's does not.

Moreover, beyond simply assuming a liberal culture-relative Sub-Moralism from the outset, ${ }^{52}$ Attfield's only argument appeals to a version of the M-OIC principle, ${ }^{53}$ so as to maintain Moral Necessity by limiting sin's scope to acts over which we may unproblematically be said to have control and bear moral responsibility. ${ }^{54}$ This provides a principled defense against the problem of agential unfairness, but Moral Necessity's problems with the sinfulness of voluntary acts or omissions remain.

\footnotetext{
52 Attfield deliberately avoids "the more pastorala spects of the idea of sin that concern confessors. [He neglects] the original biblical concept to a large extent and the usa ge of the underlying Hebrew and Greek terms" (227). He also explicitly excludes discussion of dispositional or original sinfulness, though he says that the latter is "a notion important for any doctrine of man as a moral being" (227). So while he asserts that sin is para sitic on mora lity, and characterizes this as his "main thesis," it is more accurately characterized as the Procrustean bed on which sin is laid for his a nalysis. Moreover, Attfield says that "sin is an offence a gainst God and all infractions of God's law are equally contrary to the divine will and offensive in his eyes. There are no mitigating circumstances with sin. ... the gra vity of sin does not concern men, who can leave a djudication upon this to the judgment-seat of God" (236-237; cf. Jas 2:1011). If this is so, demands of the divine law cannot simply be cut away, because they seem over-demanding, make impossible demands upon our being rather than our agency, are repugnant, or a re atrocious by our (liberal) moral lights. So he says much to undermine his own position.

53 Attfield says that anything "not under the direct control of the will ... cannot be a wrong and so a sin" (228 -229); "for sin to be possible, there must be a choice before the a gent between two lines of conduct" (235). So if one mora lly ought not- $\varphi$, it must be the case that one can choose (by directly controlled act of will) between $\varphi$ and some other line of conduct $\psi$.

54 See discussion of this tactic in Mitchell 1984, 167; Dalferth 1984, 176; and Kellenberger 1995,302-307.
} 


\subsection{Marilyn Adams's Super-Moralist Embrace of Value Conflicts}

Marilyn Adams adopts something closest to the third strategy, but she rejects the assumption that God's larger purposes are to be recovered in purely moral terms. She unreservedly rejects Moral Necessity, so her accounts side-step its problems, but it is unclear whether she recognizes the remaining problems posed by Moral Sufficiency, especially concerning (iv) uncleanness. ${ }^{55}$

Like Attfield, Adams accepts a version of moral relativism, ${ }^{56}$ on which morality is "a human institution, roughly the best framework humans generally can master and/or apply on a large scale to promote friendly and curtail anti-social behavior and attitudes" (1991, 2; see 1988, 232). But as she rejects Moral Necessity, this proves less problematic, because she can appeal to higher human-minds-independent, categorical, authoritative, normative, knowable facts about sin. For although she thinks sin is fundamentally an Anti-Moral matter of ontological incommensurability between the divine and human natures, ${ }^{57}$ she also thinks God stipulates a set of secondary criteria for sinfulness, including moral faults and breaches of distinctly non-moral norms, like norms of honor or purity:

Immutable as the ontological incommensuration itself is, the resultant formal obstacles to relationship can be easily overcome by Divine fiat: just as governments confer value on relatively worthless paper through legislation stipulating a valueequivalence to silver and gold; so God, the creator and governor of the universe, can simply count finite creatures as valuable by loving them, declare ex officio certain conditions and deeds of creatures to be honorific of Him. The result is to create at the second level a "stipulative" or "statutory" contrast among created beings and doings between what is sinful and what is worthy and acceptable and righteous in God's sight (21, original emphases).

So although human-constructed systems of evaluation and accountability, like the purity and defilement calculus, the honor code, and morality, lack the requisite normative force to command God's recognition or compliance, the norms governing sin are stipulated by God to supervene over these conventional evaluative systems, conferring upon them the requisite status to determine

\footnotetext{
${ }^{55}$ McCord Adams says that Moral Necessitarians or "Plain Moralists with the courage of their convictions dismiss (iv) uncleanness as a primitive category deservedly supplanted by the ethical" $(1991,2)$. But a similar retreat from (iv) uncleanness is neither attractive nor a vailable to her. Retreating depends on first drawing a distinction between genuine moralnorms and norms of purity or uncleanness, and her efforts to maintain such a distinction do not square well with her other meta ethicalcommitments. According to her naturalist-conventionalist picture, mora lity is a kind of social technology innovated to facilitate cooperation. But it is difficult to see why the draconian ordinances in Leviticus are not part of the best framework of constraints ancient Israel was able to master and apply large-scale to curtail what they understood (wrongly, in several cases) to be antisocial behaviors and attitudes. Indeed, she would later argue that they proved useful to ma inta ining socialorder and stability (see 1999,192). So even if Marilyn Adams could be tempted to reject the sinfulness of statutory uncleanness, her metaethical commitments cannot susta in a principled distinction between genuine normative distinction in kind between moral failings and offenses of uncleanness.

${ }^{56}$ Rogers 2002 notes that there is reason to be cautious in ascribing this view to Marilyn Adams; see 75-76, 81-83. However, Rogers may not appreciate Adams's theistic constructivism about sin or how it can explain the latter's acceptance of human-minds-independent, ca tegorical, a uthorita tive, normative, knowable facts about the indignity of things like slavery; $c f$. M. M. Adams 1999, 196. Mitchell's Super-Moralism prefigures Adams's account in several important ways, and Dalferth similarly criticizes Mitchell's moral relativism; see Mitchell 1984,172; Dalferth 1984, 180.

${ }^{57}$ She says "the logically appropriate feeling response for creatures is not [moral] guilt (which befits a rebellious use of free agency) but a sense of taint and shame" $(1991,21)$.
} 
categorical, authoritative, normative, knowable facts about $\sin .{ }^{58}$ Thus, Adams is a theistic constructivist about the norms governing sin, and this means that her relativism about human morality does not present the same problems as Attfield's.

However, because she thinks that God has elevated conflicting conventional human evaluative systems into genuine systems of divine hamartiological norms, moral norms about sin come into conflict with non-moral norms about sin. She anticipates the objection that this undermines morality and asserts that, though the evaluative systems of morality, the honor code, and the purity and defilement calculus are incongruent, all are illuminating and provide complementary pictures of human affairs. Thus, she protests:

I have not denied morality a place at the table or contested its usefulness in regulating contemporary societies. Nor have I doubted that we have moral obligations to refrain from genocide, from domestic violence, from starving or maiming other human beings. Nothing I have said calls into question our duty not to support demagogues or our moral obligation to promote more equitable distributions of this world's goods. Hence, I plead innocent to undermining morality in any of these ways $(1999,192)$.

But pleading innocence is no substitute for providing a defense. Adams fails to address how these incongruencies between moral and non-moral norms are to be understood, and Katherin Rogers (2002) details several problematic implications in her Augustinian reply.

Two things may be said on Adams's behalf. Firstly, she argues that God does not hold us morally responsible through the practice of blame, and this is in line with Maccoby's separation of ritual purity from ethics. ${ }^{59}$ Even though there may be reasons, say, to avoid, confess, or repent of one's ritual impurity for touching unclean animals or wearing mixed fibers, feelings like guilt are not apt. Indeed, the observance of merely formal requirements can imbue otherwise mund ane activities, like getting dressed or preparing meals, with worshipful significance and create a sense of intimacy with God. ${ }^{60}$ Secondly, even as the demands of moral and non-moral norms may provide reasons to avoid, confess, and repent of various sins, these reasons may not all be of equal weight, and whereas statutory sins are not intrinsically sinful, but merely mala prohibita, it is for God to determine their comparative weights.

Yet, insofar as there is any hamartiological reason to be purified of menstruation, or confess as sinful a consensual homosexual act of love, the responses that these may be less weighty, nonmoral sins (though the ordinance of capital punishment for the latter suggests otherwise), or that they should not elicit feelings like moral guilt, are still unsatisfactory. ${ }^{61}$ So much then for the partial solutions suggested by the recent philosophical literature. In the next two sections, I consider two

\footnotetext{
${ }^{58}$ For Marilyn Adams, this ratification seems to be constrained by "what is good or bad for individuals at the symbolic level" (1999, 196); $c f$. Rogers 2002,75.

59 She distinguishes between "what other people have a right to blame us for" and "what we should be ready to confess as a sin to God" (1991, 24, n. 11), and later argues that "our personal capacit ies are too limited in relation to Divine powers of thought and will for it to make sense for God to hold us responsible to God for what we do, any more than it makes sense for a mother to hold her infant responsible to her for dirty diapers" $(1999,191$, o riginal emphasis; $c f$. 1988, 232-233). Human beings lack the requisite level of agency to merit moralaccountability before God, and they lack the requisite value to command God's love. Instead, their value is conferred by divine love and their agency enabled by God's motherly care; see M. M. Adams 1991,21; 1999, 103-104; cf. Kellenberger 1995, 326 and Rogers 2002,74 .

${ }^{60}$ For a discussion of norms of etiquette as mere formalities, see Wodak 2019.

${ }^{61}$ I am grateful to Ralph Wedgwood for suggesting these responses on Marilyn Adams's behalf and discussing their merits.
} 
largely unexplored general solutions, available to Moral Necessitarians and Moral Sufficientarians alike.

\section{Hamartiological Dilemmas}

One way to develop Marilyn Adams's embrace of hamartiological value conflicts is to argue that there are genuine dilemmas between conflicting hamartiological requirements that make it practically impossible to avoid sin. After all, in her view, sin is fundamentally an immutable fact of our natures, and prominent accounts of original sin have similar implications, so perhaps the system of hamartiological norms reflects this metaphysical inevitability. To sketch the proposal, suppose that hamartiological dilemmas present themselves whenever a member of one's moral community commits one of the many offenses defined within the Levitical holiness statutes, making them ubiquitous in human social life.

Some hamartiological norms have been thought to be absolute, in the sense that they are unchangeable, exceptionless, and indefeasible. Relatedly, some sins are thought to be mortal, eternal, or unforgivable, as some have so understood blasphemy against the Holy Spirit (Mark 3:28-30; Matt 12:30-32; Luke 12:8-10), or sins that cry to Heaven for vengeance (Gen 4:10, 18:20-21; Exod 22:21-23; Deut 24:14-15). The Catechism of the Catholic Church defines mortal sins as concerning grave matter "specified by the Ten Commandments, corresponding to the answer of Jesus to the rich young man: "Do not kill, Do not commit adultery, Do not steal, Do not bear false witness, Do not defraud, Honor your father and your mother" (3.1.1.8.1858), which suggests these norms are absolute. Mortal sins must also be committed with full knowledge of the sinful character of the act or its opposition to God's law, and committed with consent sufficiently deliberate to make the act a personal choice (3.1.1.8.1859).

So suppose that someone dishonors their parents, with sufficient knowledge and deliberate consent to make it a personal choice, thereby committing a mortal sin. Furthermore, suppose (for now) that we know that omitting to sanction someone, as prescribed, for dishonoring their parents, constitutes complicity after-the-fact with grave sin, risking mortal sin. We can morally blame the offender and punish them proportionately to the (typically minor to moderate) moral wrong this offense represents. Alternatively, we can purify the community by putting the offender to death. But we cannot do both, and we commit a mortal sin if we choose to do neither. On this proposal, no matter which alternative we choose, we will fail to do something we all-things-considered ought to have done, and God will count the failure sinful.

Super-Moralists are best positioned to argue that the normative demands of distinct hamartiological kinds, with distinct aims and priorities, conflict. Indeed, Adams (1999) says the norms of morality, purity, and honor are incongruent. But recall that even she understands the norms of sin to have been minted by God, from lowly human conventional evaluative systems, to create a single system of normative symbols, as a currency for facilitat ing divine-human relations. So it might still seem surprising for God to create a system that places such grossly incompatible demands on agents. On Adams's behalf, one might respond that this is designed intentionally to reflect, not only sin's inevitability, but the fundamental incommensurability of the divine and human natures. The apparent value conflicts involved in moral dilemmas have led several philosophers to relate moral dilemmas to the incommensurability of values (Hsieh 2016), so perhaps dishonorable, impure, and (for Moral Necessitarians, other) immoral states of affairs are deemed sinful by God, in order to stipulate deliberately a set of normatively authoritative ${ }^{62}$ reasons

\footnotetext{
${ }^{62}$ For a recent overview and defense of normative authority, see Wodak 2019.
} 
or values that are incommensurable, creating hamartiological dilemmas that are apt symbols of the ontological incommensurability between the divine and human natures. ${ }^{63}$ This explanation assumes theistic constructivism, but if realists are attracted to dilemmas, perhaps they can find their own story to tell.

Narrowly construed, Moral Sufficiency's extensional problems can all be solved by accepting hamartiological dilemmas, but this solution is a double-edged sword. Maintaining Moral Sufficiency about enacting sanctions, including capital punishments or genocide mandated as matters of (iv) moral impurity, entails that these acts are morally permissible, only if enacting them is sinless. Accepting hamartiological dilemmas allows the Moral Sufficientarian to say these acts are sinful, as a matter of morality, even if sinless, as a matter of holiness. It also preserves the Moral Sufficientarian claim that all moral faults lie within the extension of sinful acts, though some morally obligatory acts, like refraining from killing or degrading moral innocents over matters of impurity, are also brought within sin's extension.

For Moral Necessitarians, all sins are moral faults, so accepting hamartiological dilemmas means also accepting moral dilemmas. ${ }^{64}$ This means that intuitively morally permissible acts or states, like (i) refraining from acts of self-sacrifice, (ii) cognitive states of unbelief in God, (iii) conative states of hatred or lust, and (iv) ritual impurities, like leprosy, and moral impurities, like consensual homosexual sex, really are morally permissible-good. But it means that these same acts or states are also morally impermissible - bad. Intuitively impermissible acts, like killing or degrading persons over matters of ritual or moral impurity, really are morally impermissiblegood. But these same acts are also morally obligatory-very bad. So while securing these good implications for Moral Necessity may help, given the bad implications, dilemmas hardly look like a solution.

Even for the Super-Moralist, who rejects Moral Necessity, accepting hamartiological dilemmas means Biting the Bullet and admitting that respecting one's moral reasons to disobey morally problematic ordinances is a sin, and this suggests something about sin that is not obviously less repugnant or atrocious than the original version of the problems, making (perhaps grave or mortal) hamartiological failures out of having the minimal moral decency to not kill or demean someone.

For theistic constructivists, hamartiological dilemmas plausibly also undermine God's standing to blame us for $\sin ,{ }^{65}$ or (as Marilyn Adams would have it) God's standing to receive confession for $\sin .{ }^{66}$ For by making it practically impossible to avoid sin, God becomes involved

\footnotetext{
${ }^{63}$ See M. M. Adams 1991,21, for her discussion of how statutory sin serves this symbolic purpose.

64 In order to avoid the problem of deontic logical inconsistency, which arises for moral dilemmas (see McConnell 2018, $\S \S 4-5)$, Lemmon 1962 and Trigg 1971 argue that the existence of moraldilemmas provide count erexamples to the M-OIC principle. As we saw in $\$ 3.2$, maintaining Moral Necessity, about the sinfulness of nonvoluntary (ii) cognitive, (iii) conative, or (iv) bodily states, represents a prima facie challenge to the M-OIC principle. One way to meet this challenge is to say that these sins provide (additional) counterexamples to this principle. So Moral Necessitarians about the sinfulness of nonvoluntary states have independent rea son to reject a wholly general M-OIC principle. If they are prepared to do so, they can also readily accept the existence of moral dilemmas, while avoiding deontic logical inconsistency in the way that Lemmon and Trigg recommend.

${ }^{65}$ For a helpful introductory discussion and defense of God's moralstanding to blame, see Todd 2018.

${ }^{66}$ As we learned in $\$ 4.3$, Marilyn Adams thinks God elevates human evaluative systems into criteria of statutory sin, thereby involving humans in the determination of what counts as sinful, and she also argues that God does not hold us morally responsible through the practice of blame; see footnote 59 above. So worries about God's standing to hold us accountable for sin need more work to get off the ground. But it is difficult to see why one should be ready to confess as sin one's violations of conflicting requirements of morality and uncleanness (among others, perhaps), if neither one's culture nor oneself, recognizes all of the relevant evaluative systems as legitimate. For if neither oneself or one's culture recognize all of the relevant evaluative systems as legitimate, it cannot be said that the mea sure you
} 
in our (statutory) sinfulness in a way that may make God complicit. After all, when a blamer is objectionably involved in the very act for which they are condemning a blameworthy agent, the blameworthy agent may felicitously retort: "you forced me to do it," or "you left me with no alternative" (Cohen 2006, 126). Similarly, God's involvement in rigging the normative game, would force us into a position where, through no individual fault of our own, we have no alternative but to sin. Alternatively, the problem might be that enacting conflicting norms would betray a lack of genuine commitment to the values underlying each norm, even though it is by these values that God would presume to condemn sin (Todd 2018, 41). Whichever explanation we prefer for the undermining of standing, on Adams's picture, dilemmas would suggest a deeper normative or legislative incompetence on God's part, which would subvert any symbolic value God might confer on these lowly human norms to make them genuinely authoritative hamartiological norms. All told, these look like significant costs of accepting hamartiological dilemmas, so I think this "solution" creates more problems than it solves. ${ }^{67}$

\section{Defeasible Sinfulness and the Pedagogical Problem of Evil}

Setting aside the possibility of dilemmas, perhaps problematic hamartiological requirements should instead be understood as having pro tanto stringency, such that they can be overridden in some cases by countervailing considerations. ${ }^{68}$ For example, short of meeting the conditions for mortal sin, a sin is considered venial or pard onable in the Catechism of the Catholic Church, either because the agent fails to be responsible in the required sense or because it violates a defeasible

or even your moral community gives is the measure you are getting from God, pace Matt 7:2. So even if God's moral standing to blame is not at issue in Adams's understanding, God's standing to receive confession for sin still looks to be undermined for the same kinds of reasons as those outlined above.

67 Naturally, Christians must also ask whether Christ could live a sinless life under such conflicting normative requirements (2 Cor 5:21; John 8:46; Heb 4:15, 7:26; 1 Pet 2:22; 1 John 3:5). John 8:1-11 suggests he could. Wanting to trap Jesus between the Levitical requirement of capital punishment for the grave sin of adultery and Roman law, which generally retained for itself the right of life and death, particularly a ga inst lynch mobs (Corley 1992,850-851), some of his religious opponents presented him with a woman caught in adultery. They challenged him: "the law Moses commanded us to stone such women. Now what do you say?" In response, "Jesus bent down and wrote with his finger on the ground. When they kept on questioning him, he straightened up and said to them, "Let anyone among you who is without $\sin$ be the first to throw a stone at her." And once a gain he bent down and wrote on the ground [the sins of each of them ]." The trap defeated, his opponents departed, and Jesus a sked her: "Woman, where are the y? Has no one condemned you?" She said, "No one, sir." And Jesus said, "Neither do I condemn you. Go your way, and from now on do not sin again."

Though the text of John 8:1-11 is of dubious provenance and likely a later a ddition to John's gospel, Christian tradition has long credited the story as though it were non-a pocryphal. It is also consistent with concerns for hypocrisy a scribed to Jesus in the other canonical gospels (see Mark 7:6; Matt 6:2-16, 7:1-5, 15:7, 22:18, 23:13-29, 24:51; Luke $6: 37-42,12: 56,13: 15 ; c f$. Ps 26:4; Sir 1:29, 32:15,33:2), as well as John's earlier statement that "God did not send his Son into the world to condemn the world, but to save the world through him" (John 3:17; see also Matt 9:6).

On the Christian understanding of Jesus' divinity, he appears to invoke his divine authority and mission to forgive sins, rather than condemn them, offering only correction and a challenge to repent. On some theories of divine forgiveness, God's forbearance to mete out (deserved) penalty just is God's forgiveness (e.g., Londey 1986, Brien 1989, or Geuras 1992; see also Warmke 2017,6-7 of 9). But should the proper normative conditions for forgiveness, like an a pology, repentance, or a change of heart, not obta in, Jesus might alterna tively exercise his divine authority to condemn the sin at a later date, promising a future reckoning (e.g., Matt 11:20,12:41-42; Luke 10:13-15). Thus, by exercising his authority to forgive sins or delay God's judgment, Jesus could dissolve any hamartiological dile mma he might encounter, while remaining sinlessly obedient to norm(s) of sin he chose to leave intact.

${ }^{68}$ Shea 2018 briefly considers this possibility but sets it a side, because it conflicts with his reconstruction of Aquinas's attempt to Recover God's Larger Moral Purpose in commanding the Israelites to "plunder" the Egypt ians during the Exodus, as Aquinas views the prohibition a ga inst theft as a moral absolute; see Shea 2018,282-283. 
hamartiological norm. So perhaps an agent's hamartiological reasons to refrain from venial sins can be outweighed or defeated by other considerations, including reasons to refrain from more serious venial or mortal sins.

For illustration, suppose once again that someone dishonors their parents, with full knowledge of the sinful character of the act, and with consent sufficiently deliberate to make it a personal choice, thereby committing a mortal sin. We can blame the offender in proportion to the (often minor to moderate) moral wrong the dishonor represents. Or we can purify the sin by putting the offender to death. But it seems perverse to deem the offence minor enough to merit correction, only to later execute the offender for the very same offense, so we ought not do both. Can our hamartiological reasons to impose one of these sanctions defeat the pro tanto sinfulness of omitting the other?

Intuitively, the moral reasons against killing someone over a minor or moderate moral wrong (at least) defeat any reasons of purity to put the offender to death. Many biblical sources also insist that the weight of hamartiological reasons to refrain from sins varies considerably with the kind of sin (whether or not they all are, or all involve, moral reasons, as Moral Necessitarians must insist). For example, Jesus says that some matters of the Law, including matters of justice, mercy, and faith, are weightier and are to be given priority over minor matters of holiness, like the tithing of spices (Matt 23:23; Luke 11:42; cf. Lev. 27:30-32; 1 Sam 15:22; Prov 21:3; Isa 1:1117; Hos 6:6; Mark 12:33; Matt 9:13; 12:7). Elsewhere, Jesus seems to acknowledge that demands across these domains can genuinely conflict, requiring weightier matters to (at least) outweigh the lesser in practical reasoning (Mark 2:23-27; Matt 12:1-8; Luke 6:1-5; cf. 1 Sam 21:1-7; Exod 29:32-33; Lev 24:5-9). So perhaps responding to hamartiological reasons in the right way does not require a radical departure from our intuitive judgments about what we all-things-considered have most reason to do. In that case, our reasons to hold the offender morally responsible outweigh and defeat our reasons to purify the community by their execution.

Accepting sin's defeasibility solves the problems of atrocity and repugnance for Moral Necessitarians. For maintaining Moral Necessity about the sinfulness of deliberately omitting genocide, capital punishments, and milder sanctions for offenses of (iv) ritual or moral impurity, only entails that such disobedience is morally wrong if it is sinful. But if it is only sinful pro tanto, the hamartiological reason to obey (or not disobey) can be defeated by our moral reasons against committing genocide, murder, or degrading treatment of persons, the atrocious and repugnant implications of Moral Necessity are avoided. Similarly, if other kinds of considerations, like our mental limitations, can be weighed against the pro tanto sinfulness of defined cognitive and conative failures, or prudential considerations and obligations to dependents weighed against the pro tanto sinfulness of failing to make costly sacrifices, then Moral Necessity's unfair and overdemanding implications can also be eased. Finally, if the pro tanto sinfulness of all of the above can be outweighed or partly balanced off by other hamartiological considerations, the sinlessness of sanctioning them will be too. ${ }^{69}$ In that case, Moral Sufficiency's problems are also addressed.

69 Moral Sufficiency's problems arise from entailing the moral permissibility of (sinlessly) sanctioning morally faultless sins. Suppose A has some pro tanto reason to not- $\varphi$, but A is all-things-considered justified in $\varphi$-ing, and $\varphi$ ing involves seriously wronging someone. Some argue we are still required to (sinlessly) sanction A for $\varphi$-ing (see e.g., de Wijze 2013 and Corvino 2015; cf. Roadevin 2019). In such cases, the plausibility of sanctioning A depends on the seriousness of the wronging involved in $\varphi$-ing. For where $\varphi$-ing involves a less serious wronging, the plausibility of sanctioning A is in doubt, and the specific problems posed above for Moral Sufficiency do not arise. On the other hand, where $\varphi$-ing involves a serious moral wronging, $\varphi$-ing is not a morally faultless sin, but a morally serious wronging whose sinfulness ex hypothesi is outweighed or defeated, and a gain the specific problems discussed a bove do not arise. Yet, if the sinfulness of a morally serious, sanctionable wronging can be outweighed or defeated, it presents a prima facie counterexample to Moral Sufficiency. So Moral Sufficientarians must either explain how 
However, if failing to sanction sins of impurity is merely sinful pro tanto, it is difficult to imagine any case where their sinfulness would not be defeated by the moral reasons against wrongful killing and disrespectful treatment of persons. Indeed, the weight of our moral reasons arguably trump any amount of considerations for impurity (Griffin 1986; $c f$. Hsieh 2016). So defeasibility obviates the need to identify these offences of impurity as "sins" in the first place, let alone mandate sanctions like ind iscriminate genocide or capital punishment. At first, this may look like the right result, but it imposes a significant explanatory burden on any account of sin and a further explanatory burden on parties to the Moral Consensus.

\subsection{Reinterpreting God's Intent with Defeasible Sinfulness}

One might be tempted to adapt sin's defeasibility in service to the second strategy of Reinterpreting God's Intent. For instance, Augustine argues for a purely theoretical interpretation of these kinds of ordinances: "Those things, again, whether only sayings or whether actual deeds, which appear to the inexperienced to be sinful, and which are ascribed to God, or to men whose holiness is put before us as an example, are wholly figurative, and the hidden kernel of meaning they contain is to be picked out as food for the nourishment of charity" (2020, III.12) ${ }^{70}$ Thus, in order to deny that the problematic passages contain genuine divine commands and permissions, one could argue that, interpreted defeasibly, these morally problematic passages are emptied of their seemingly objectionable normative content, and then provide some justification for their faux-identification as sanctionable "sins." But this last step presents a significant challenge.

The relevant ordinances take the form of general hamartiological principles ordained by God (and therefore, general moral principles, per Moral Necessity), so if they are purely figurative, they are also dangerously misleading. After all, the Hebrew scriptures depict the Israelites as having complied with the ordinances for capital punishment and genocide on several occasions. For example: "Then Israel made a vow to the Lord and said, "If you will ind eed give this people into our hands, then we will utterly destroy their towns." The Lord listened to the voice of Israel, and handed over the Canaanites; and they utterly destroyed them and their towns ..." (Num 21:23 ; cf. Josh 6:21; 10:20; 11:11). As Wes Morriston (2012) reports, "The consensus of mainstream biblical scholarship is that the genocides did not take place as described in the biblical texts ... but this does nothing to remove the moral problem ... divinely mandated genocide is included in a founding story that the ancient Israelites told themselves - a story that has helped to shape the theological traditions of both Jews and Christians" (119). ${ }^{71}$ These theological traditions, in turn, shape the moral understandings of their adherents, and they present these general hamartiological/moral principles as having been obeyed by exemplars of their faith.

\footnotetext{
serious, sanctionable wrongings can be morally faultless in such cases (so as not to be sufficient for sin) or deny the possibility of such cases (e.g., by insisting that hamartiologicalnorms a gainst the relevant kinds of serious wrongs are absolute, not defeasible). My thanks to Jonathan Quong for pressing me on this point.

70 A purely theoretical interpretation of the ordinance of capital punishment for a stubborn and rebellious son (Deut $21: 18-21)$ is similarly contemplated in the Talmud, where it is stated that "Itnever happened and it never will happen" and that the law was given merely "that you may study it and receive reward" (i.e., for pure study; Tosef., Sanh. 11:6; Sanh. 71a). The Mishnah (Mak. 1:10; Mak. 7a) also says that a Sanhedrin court that orders the death penalty once in seven years (or once in seventy years, according to Rabbi Eleazer b. Azariah) is considered murderous or bloody, while Rabban Simeon b. Gamaliel opines that one passing no death sentences at all would only multiply murderers in Israel. See Cohn, Rabinowitz, and Elon 2008, 447.

${ }^{71}$ Morriston includes several representative statements from biblical scholars in a footnote; see Morriston 2012, 119, n. 7.
} 
As a result, the Talmud records continued court-ordered executions for offenses of impurity, including the stoning of a man for Sabbath-breaking (Sanh. 46a), the burning alive of a priest's daughter for adultery (Sanh. 7:2), and extra-judicial killings are also recorded, including the hanging of eighty women in Ashkelon for witchcraft (Cohn, Rabinowitz, and Elon 2008; Sanh. 6:4, cf. Lev 19:31; 20:27; Sanh. 46a). We also know, from work on the philosophy of religious trauma, that these ordinances continue to be used to rationalize comparatively lesser atrocities like child abuse and the indoctrination of traumatic religious beliefs. Consider, for example, this factually inspired case discussed by Michelle Panchuk (2018):

A young child is repeatedly and brutally beaten by her Christian parents. She is told that since God commanded the Israelites to stone their rebellious children, anything they do to her short of that is divinely approved and morally deserved. And she believes them. One night, they lock her out of the house as punishment for some misdeed. Sitting alone, bruised and bleeding, gazing at the stars, the girl has an overwhelming sense of the presence of God - a presence utterly terrifying because she perceives it to be of a being who delights in her suffering (514). ${ }^{72}$

When you are among the victims of the misinterpretation and misapplication of these ordinances, the Augustinian claim, that God did not intend for them to be understood that way, rings hollow. These victims understandably ask "why does God care so little for me that God said this, knowing I would be the collateral damage of those who dared to think God actually meant what God said?"73

Thus, even if the learned opinion among Jewish and Christian scholars is that these ordinances were rarely or never to be applied in practice, by taking the form of general hamartiological and perhaps moral principles, they enjoin misunderstanding and misapplication. Mitchell opines that it is natural for the deeply religious "to confuse a sense of their inadequacy as finite creatures before the infinite glory of God with the guilt that properly accompanies only moral failure. The sense of finitude in morally sensitive people who are also religious inclines them to assume moral guilt where none can reasonably be imputed" $(1984,166)$. But if this kind of confusion is natural, God's authorship of these ordinances is all the more problematic.

Without the benefit of foreknowledge, at best, God would be culpably negligent to lay down faux-moral ableist, misogynistic, homophobic, and xenophobic sanctions, including death penalties and genocide, for God would be knowingly misleading sincere submissive devoteesnaturally inclined to confuse their sense of what is inadequate or their aesthetic sense of impurity for moral failings - to commit (mass) murder and other moral evils, on the basis of reasons constructed to appear normatively authoritative and overriding of other considerations. With the benefit of foreknowledge, God is complicit in every gratuitous death and lesser evil meted out in obedience to these faux-commands and exercise of these faux-permissions. Even in the knowledge that (eventually) intelligent people will discover their limited or empty practical import and discover their deeper theological meanings, given more straightforward pedagogical alternatives, God would be sacrificing lives and allowing suffering without sufficient justification. For any

\footnotetext{
72 As Panchuk explains in a footnote: "Although this case is fictional, it is inspired by a narrative offered anonymously at Homeschoolers Anonymous. Being personally acqua inted with the author, I can speak for the veracity of the story and have gotten permission to use an adaptation of it in this context" (see Mary 2013). Panchuk 2019 reports similar experiences of her own: "Mine were the vain attempts to find joy in submitting to abuse inflicted in the name of God, the name of the cross, the name of the atoning Christ. When the cross is what you deserve, anything short of that is "grace." So I listen to defenses of penal substitution and vicarious punishment with shaking hands, racing heart, and tears welling in my eyes (69).

${ }^{73}$ My thanks to Kenny Pearce and especially Michelle Panchuk for their very helpful discussion of this point.
} 
resulting evils would have to be justified by appeal to the value of the spiritual food to which Augustine appeals, and the value of this spiritual food, limited by its convoluted method of delivery, is just not plausibly of comparable value to the lives lost and suffering inflicted by its convoluted method of delivery. So accepting sin's defeasibility, in service to the second strategy of Reinterpreting God's Intent, looks untenable, because it invites a potent version of the evidential problem of apparently gratuitous evils, arising from God's own moral misguidance: a pedagogical problem of evil.

\subsection{Rejecting God's Authorship with Defeasible Sinfulness}

Alternatively, one could adapt Morriston's argument that moral correction runs in both directions between the believer and the scriptures:

Sometimes, reflecting on a particular passage may bring us up short and help us to see something new. At other times, our moral intuitions (themselves partly formed by reflecting on Scripture) may give us good reason for making a negative ethical judgment about a particular text. As we struggle with the texts, we may learn from them; but we may also have to pass judgment on them. ... [and if] we engage in ethical criticism of the genocide texts, we are continuing a process begun by the biblical authors themselves $(2012,134) .{ }^{74}$

Following this model, one could argue that the scriptural bases for accepting defeasible sinful-ness are best interpreted as reasons to Reject God's Authorship of those problematic commands and permissions seemingly trumped by commonsense moral considerations. Indeed, Morriston himself contends that the genocide passages provide us with strong prima facie reasons to reject claims of their authoritative inspiration by God, and having been unconvinced by arguments against Rejecting God's Authorship (2009) and attempts to Recover God's Larger Moral Purposes in the genocide passages (2012), Morriston concludes that God did not in fact command genocide. So one could extend this argument, Rejecting God's Authorship of more or all of the problematic ordinances discussed above.

But this still implies that, however natural their mistakes, God's people have dangerously misled one another at a deeper level, with respect to the inspiration, authority, and reliability not only of their core canonical scriptures but of God's moral guidance of their communities, so that at least many of them have been complicit in gratuitous killings and lesser moral evils, whether meted out in zealous obedience to faux-commands, or tolerated in deference to faux-permissions. So while defeasible sinfulness seems well-motivated, solves the problems of atrocity and repugnance, and eases the problems of over-demandingness and agential unfairness, for Moral Necessitarians and Sufficientarians alike, if it is employed to Reject God's Authorship of problematic ordinances related to sin, it leaves the rejected ordinances no less misleading. And while denying their divine authority undercuts their dangerousness going forward, it lays their gratuitous historical consequences at the feet of complicit religious communities and perhaps God as well. Therefore, this version of the first strategy cannot succeed on its own without some effort to explain God's larger purposes.

\footnotetext{
${ }^{74}$ Morriston assumes here that moral intuition can reliably inform our judgments about what really is or is not sinful, but for anyone who rejects Moral Necessity, this is not a safe assumption. To a dapt Morriston's argument, absent the a ssumption of MoralNecessity, one must identify suitable ana logues to moral intuition (them selves also partly formed by reflection on scripture), including, perhaps, a esthetic intuition; see especially chapter 7 of M. M. Adams 1999.
} 


\subsection{Recovering God's Larger Purposes with Defeasible Sinfulness?}

Christian thinkers may still decide to embrace the defeasibility of pro tanto sinfulness as part of a solution to one or more of the four extensional problems discussed in this paper, but they if do, they owe us an explanation for why God has allowed morally misleading ordinances about sin to drastically misshape the behavior of believers and warp their understand ings of God's will. Parties to the Moral Consensus must further explain how this is compatible with their commitment(s) to Moral Necessity or Moral Sufficiency. But it is not obvious these moralistic commitments are compatible with the recognition that God has allowed core teachings about sin to morally mislead believers so badly. If moral fault really is necessary or sufficient for sin to obtain, why does the prevention of moral fault not impose a more effective constraint on Judeo-Christian teachings about sin itself? Is there a way to Recover God's Larger Purposes for allowing such moral misguidance, while preserving God's standing to hold us accountable for moral faults in the way that Moral Necessity or Moral Sufficiency imply? These are difficult questions, which we cannot answer here. For now, we should recognize that hefty explanatory burdens await those who appeal to sin's defeasibility to resolve the four extensional problems discussed in this paper.

\section{Conclusions}

In this paper, we have seen that nearly all Christian thinkers defend, or at least assume, some kind of close extensional relationship between sin and moral fault: all sins are moral faults, all moral faults are sins, or all the above. So there is a "Moral Consensus" around the disjunction of Moral Necessity or Moral Sufficiency. Despite substantive disputes about what counts as sin in the Bible, we have also seen that maintaining Moral Necessity or Moral Sufficiency about the biblical catalogue of sins creates four problems: (1) moral over-demandingness, (2) agential unfairness, (3) moral repugnance, and (4) moral atrocity. After surveying some partial solutions suggested in the recent philosophical literature, I considered two largely unexplored general solutions, available to all parties in the Moral Consensus: (a) genuine hamartiological dilemmas, and (b) the defeasibility of pro tanto sinfulness. I showed that while much can be said for both solutions, dilemmas create more problems than they solve.

However, defeasible sinfulness seems especially well-motivated, solves the problems of moral atrocity and repugnance, and eases the problems of over-demandingness and agential unfairness, for Moral Necessitarians and Moral Sufficientarians alike. So it is clearly an attractive solution to the problems we have identified, and one worthy of further consideration. Yet, even if the defeasibility of pro tanto sinfulness is embraced as part of a solution to these problems, Christian thinkers owe us an explanation for why God has allowed morally misleading ordinances about sin to drastically misshape the behavior of believers and warp their understand ings of God's will. For parties to the Moral Consensus, any such explanation must remain compatible with their commitment(s) to Moral Necessity or Moral Sufficiency. But it is not obvious these moralistic commitments are compatible with the recognition that God has allowed core teachings about sin to morally mislead believers so badly. If moral fault really is necessary or sufficient for sin to obtain, why has its prevention not imposed a more effective constraint on Judeo-Christian teachings about the very topic of sin? Is there a way to resolve this pedagogical problem of evil, while preserving God's standing to hold us accountable for moral faults, as Moral Necessity or Moral Sufficiency imply? These are difficult questions, which we cannot answer here. For now, we should recognize that hefty explanatory burdens await those who appeal to sin's defeasibility to resolve the extensional problems discussed in this paper. So while a number of theologians and 
philosophers have opposed what they take to be overly moralizing approaches to the doctrine of sin, insofar as they remain party to the Moral Consensus about sins, they may need to consider a more radical separation of sin and moral fault. ${ }^{75}$

\section{References}

Adams, Marilyn McCord. 1988. "Theodicy Without Blame.” Philosophical Topics 16 (2): 215245. doi: 10.5840/philtopics198816220.

---. 1991. "Sin as Uncleanness.” Philosophical Perspectives 5, Philosophy of Religion: 1-27. doi: $10.2307 / 2214089$.

---. 1999. Horrendous Evils and the Goodness of God. Ithaca, NY: Cornell University Press.

Adams, Robert Merrihew. 1985. "Involuntary Sins." The Philosophical Review 94 (1): 3-31. doi: $10.2307 / 2184713$.

---. 1987. "Divine Commands and the Social Nature of Obligation." Faith and Philosophy 4 (3): 262-275. doi: 10.5840/faithphil19874343.

Augustine. 397-426. "On Christian Doctrine, in Four Books." In Christian Classics Ethereal Library. Last accessed July 15, 2020: https:/ccel.org/ccel/augustine/doctrine/.

Attfield, David G. 1984. “The Morality of Sins.” Religious Studies 20 (2): 227-237.

Basu, Rima. 2018. “Can Beliefs Wrong?” Philosophical Topics 46 (1): 1-17. doi: 10.5840/philtopics20184611.

Basu, Rima; and Mark Schroeder. 2019. "Doxastic Wronging." In Pragmatic Encroachment in Epistemology, edited by Brian Kim and Matthew McGrath. Routledge: 181-205.

Bayle, Pierre. 1965 (1686-1687). "Commentaire philosophique sur ces paroles de Jesus-Christ, 'Contraine-les d'entrer'.” In Oeuvres Diverses, Volume 2. Olms.

Bergmann, Michael; Michael J. Murray; and Michel C. Rea. 2011. "Introduction.” In Divine Evil: The Moral Character of the God of Abraham, edited by Michael Bergmann, Michael J. Murray, and Michael C. Rea. Oxford University Press: 1-21.

Blidstein, Moshe. 2017. Purity, Community, and Ritual in Early Christian Literature. Oxford University Press. doi: 10.1093/oso/9780198791959.001.0001.

\footnotetext{
75 Acknowledgments: I wish to thank Ralph Wedgwood, Jonathan Quong, an anonymous referee for Religious Studies, and an anonymous referee for the Journal of Analytic Theology for their extensive comments on earlier versions of this paper. I am also grateful to Mark Schroeder, Michelle Panchuk, Kenny Pearce, Alida Liberman, Erik Encarnacion, Leigh Vicens, Lorraine Street, Maegan Fairchild, and Renee Jorgensen for helpful conversations and suggestions a long the way. Finally, I want to thank the participants of the 2019 SLU Graduate Student Conference, especially my commentator, James Dominic Rooney, as well as participants in the 4th Theistic Ethics Workshop, and audiences at the 2018 meeting of the Canadian Society of Christian Philosophers, and the 2017 meeting of the Atlantic Region Philosophers' Association, for their comments and discussions of earlier related work.
} 
Bonhoeffer, Dietrich. 1995 (1949). Ethics, translated by Neville Horton Smith and edited by Eberhard Bethge. Simon and Schuster.

Borg, Marcus J. 1987. Jesus, a New Vision: Spirit, Culture, and the Life of Discipleship. Harper \& Row.

---. 1994. Jesus in Contemporary Scholarship. Valley Forge, PA: Trinity Press International.

Brien, Andrew. 1989. “Can God Forgive us our Trespasses?” Sophia 28 (2): 35-42. doi: 10.1007/BF02789857.

Brunner, Emil. 1957 (1939). Man in Revolt: A Christian Anthropology. Olive Wyon (Trans.) Lutterworth.

Buchanan, George W. 1970. The Consequences of the Covenant. Brill.

Büchler, Adolf. 1928. Studies in Sin and Atonement in the Rabbinic Literature of the First Century. Oxford University Press.

Catholic Church. 2012. "The Gravity of Sin: Mortal and Venial Sin.” In Catechism of the Catholic Church (Second Edition) (1854-1864). Libreria Editrice Vaticana. Last accessed July 15, 2020: http://www.vatican.va/ archive/ENG0015/_P6C.HTM.

Coady, C. A. J. 2012. "Moralism and Anti-Moralism: Aspects of Bonhoeffer's Christian Ethic." Sophia 51 (4): 449-464. doi: 10.1007/s11841-012-0340-2.

Cohen, Gerald A. 2006. "Casting the First Stone: Who Can, and Who Can't, Condemn the Terrorists?" Royal Institute of Philosophy Supplement 58: 113-136. doi: $10.1017 / \mathrm{S} 1358246106058061$.

Cohn, Haim Hermann; Louis Isaac Rabinowitz; and Menachem Elon. 2008. "Capital Punishment.” In Encyclopaedia Judaica, Volume 4 (Second Edition), edited by Michael Berenbaum and Fred Skolnik. Macmillan Reference USA in association with the Keter Publishing House: 445-451.

Corley, Bruce. 1992. "Trial of Jesus.” In Dictionary of Jesus and the Gospels, edited by Joel B. Green, I. Howard Marshall, and Scot McKnight. InterVarsity Press: 841-854.

Corvino, Fausto. 2015. "Punishing Atypical Dirty Hands." International Journal of Applied Philosophy 29 (2): 281-297. doi: 10.5840/ijap201612755.

Couenhoven, Jesse. 2009. "What is Sin? A Differential Analysis." Modern Theology 25 (4): 563-587. doi: 10.1111/j.1468-0025.2009.01555.x.

Dalferth, Ingolf. 1984. "How Is the Concept of Sin Related to the Concept of Moral Wrongdoing?" Religious Studies 20 (2): 175 -189.

de Wijze, Stephen. 2013. “Punishing 'Dirty Hands'—Three Justifications.” Ethical Theory and Moral Practice 16 (4): 879-897. doi: 10.1007/s10677-012-9396-x. 
Douglas, Mary. 2002 (1970). Purity and Danger: An Analysis of the Concepts of Pollution and Taboo. Routledge Classics.

Frymer-Kensky, Tivka. 1983. "Pollution, Purification, and Purgation in Biblical Israel." In The Word of the Lord Shall Go Forth: Essays in Honor of David Noel Freedman in Celebration of His Sixtieth Birthday, edited by Carol L. Meyers and M. O'Connor. Eisenbrauns: 399-410.

García Martínez, Florentino. 1995. “The Problem of Purity: The Qumran Solution.” In The People of the Dead Sea Scrolls: Their Writings, Beliefs, and Practices, edited by Florentino García Martínez and Julio Trebolle Barrera. Brill: 139-157.

Gavin, Frank. 1928. The Jewish Antecedents of the Christian Sacraments. Society for Promoting Christian Knowledge.

Geuras, Dean. 1992. “In Defense of Divine Forgiveness: A Response to David Londey.” Sophia 31 (1-2): 65-77. doi: 10.1007/BF02772354.

Griffin, James. 1986. Well-Being: Its Meaning, Measurement and Importance. Clarendon Press.

Haber, Susan. 2008. "Part I: Bibliographic Studies.” In They Shall Purify Themselves: Essays on Purity in Early Judaism, edited by Adele Reinhartz. Society of Biblical Literature: 7-71.

Harrington, Hannah K. 1993. The Impurity Systems of Qumran and the Rabbis: Biblical Foundations. Scholars Press.

Hayes, Christine. 2002. Gentile Impurities and Jewish Identities: Intermarriage and Conversion from the Bible to the Talmud. Oxford University Press.

---. 2007. "Purity and Impurity, Ritual.” In Encyclopaedia Judaica, Volume 16 (Second Edition), edited by Michael Berenbaum and Fred Skolnik. Macmillan Reference USA in association with the Keter Publishing House: 746-756.

Himmelfarb, Martha. 1999. "Sexual Relations and Purity in the Temple Scroll and the Book of Jubilees." Dead Sea Discoveries 6 (1): 11-36. doi: 10.1163/156851799X00027.

Hoffmann, David Z. 1905. Das Buch Leviticus, Volume 1. Berlin, DE: M. Poppelauer.

Holtz, Gudrun. 2012. 'Purity Conceptions in the Dead Sea Scrolls: 'Ritual-Physical' and 'Moral' Purity in a Diachronic Perspective." In Purity and the Forming of Religious Traditions in the Ancient Mediterranean World and Ancient Judaism, edited by Christophe Nihan and Christian Frevel. Brill: 519-536.

Hsieh, Nien-he. 2016. "Incommensurable Values." In The Stanford Encyclopedia of Philosophy (Spring 2016 Edition), edited by Edward N. Zalta. Last accessed July 15, 2020: https://plato.stanford.edu/archives/spr2016/entries/value-incommensurable/.

Kazen, Thomas. 2010. Jesus and Purity Halakhah: Was Jesus Indifferent to Impurity? Pennsylvania State University Press.

Kellenberger, James. 1995. Relationship Morality. The Pennsylvania State University Press. 
Kierkegaard, Søren. 1989 (1849). The Sickness Unto Death, translated by Alastair Hannay. Penguin Classics.

Kilcullen, John. 1983. “Antoine Arnauld Against Philosophic Sin.” Philosophy Research Archives 9: 595-637.

Kirkpatrick, Matthew D. 2013. "Bonhoeffer, Kierkegaard, and the Teleological Suspension of the Ethical: The Beginning or End of Ethics?" In Ontology and Ethics: Bonhoeffer and Contemporary Scholarship, edited by Adam C. Clark and Michael Mawson. Pickwick Publications: 86-101.

Klawans, J. 2000. Impurity and Sin in Ancient Judaism. Oxford University Press.

Konkel, Michael. 2012. "The System of Holiness in Ezekiel's Vision of the New Temple (Ezek 40-48)." In Purity and the Forming of Religious Traditions in the Ancient Mediterranean World and Ancient Judaism, edited by Christophe Nihan and Christian Frevel. Brill: 429455.

Lein, John Elliott. 2015. “An Abomination in Leviticus 18:22.” In J. Elliott Lein. Gay Marriage and the Bible (Self-published book manuscript). Last accessed July 15, 2020: https://www.gaymarriageand thebible.com/an-abomination-in-leviticu s-18.

Lemmon, E. J. 1962. “Moral Dilemmas.” The Philosophical Review 71 (2): 139-158.

Lewis, Charles. 1983. "Divine Goodness and Worship Worthiness." International Journal for Philosophy of Religion 14 (3): 143- 158. doi: 10.1007/BF00136891.

Lipinski, Edward; and Louis Jacobs. 2007. "Sin.” In Encyclopaedia Judaica, Volume 18 (Second Edition), edited by Michael Berenbaum and Fred Skolnik. Macmillan Reference USA in association with the Keter Publishing House: 621-625.

Londey, David. 1986. “Can God Forgive us our Trespasses?” Sophia 25 (1): 4-10. doi: $10.1007 / \mathrm{BF} 02912217$.

Maccoby, Hyam. 1999. Ritual and Morality: The Ritual Purity System and Its Place in Judaism. Cambridge University Press.

Malina, Bruce J. 1993. The New Testament World: Insights from Cultural Anthropology (Revised Edition). Westminster/John Knox Press.

Mary. 2013. "Home Is Where the Hurt is: Mary's Story," Parts Two and Three. Homeschoolers Anonymous. Last accessed July 15, 2020:

https:/homeschoolersanonymous.net/2013/04/03/home-is-where-the-hurt-is-marys-storypart-two/ and https:/homeschoolersanonymous.net/2013/04/05/home-is-where-the-hurtis-marys-story-part-three/.

McConnell, Terrance. 2018. "Moral Dilemmas" In The Stanford Encyclopedia of Philosophy (Spring 2016 Edition), edited by Edward N. Zalta. Last accessed July 15, 2020: https://plato.stanford.edu/archives/fall2018/entries/moral-dilemmas/. 
Milgrom, Jacob. 1976. "Israel's Sanctuary: The Priestly Picture of Dorian Gray.” Revue Biblique 83: 390-399.

Miller, Christian. 2018. "What Should Theists Say about Constructivist Positions in Metaethics?" In Religious Ethics and Constructivism: A Metaethical Inquiry, edited by Kevin Jung. Routledge: 82-103.

Mitchell, Basil. 1984. "How Is the Concept of Sin Related to the Concept of Moral Wrongdoing?” Religious Studies 20 (2): 165-173.

Moore, George F. 1919. The History of Religion, Volume 2. Charles Scribner's Sons.

Morriston, Wes. 2009. "Did God Command Genocide? A Challenge to the Biblical Inerrantist." Philosophia Christi 11 (1): 7-26.

---. 2012. "Ethical Criticism of the Bible: The Case of Divinely Mandated Genocide." Sophia 51: 117-135. doi: 10.1007/s11841-011-0261-5.

Neusner, Jacob. 1973. The Idea of Purity in Ancient Judaism. Brill.

Newton, Michael. 1985. The Concept of Purity at Qumran and in the Letters of Paul. Cambridge University Press. doi: 10.1017/CBO9780511555022.

Neyrey, Jerome H. 1986. “The Idea of Purity in Mark’s Gospel.” Semeia 35: 91-128.

Niebuhr, H. Richard. 1935. "Man the Sinner.” The Journal of Religion 15 (3): 272-280.

Niebuhr, K. P. Reinhold. 1943. The Nature and Destiny of Man, Volume I: Human Nature. Nisbet \& Co.

Nihan, Christophe. 2012. "Forms and Functions of Purity in Leviticus." In Purity and the Forming of Religious Traditions in the Ancient Mediterranean World and Ancient Judaism, edited by Christophe Nihan and Christian Frevel. Brill: 311-367.

O’Neil, Arthur Charles. 1912. "Sin.” In The Catholic Encyclopedia, Volume 14. New York: Robert Appleton Company. Last accessed July 15, 2020: http://www.newadvent.org/cathen/14004b.htm.

Otto, Rudolf. 1958. The Idea of the Holy, translated by John W. Harvey. Oxford University Press.

Panchuk, Michelle. 2018. "The Shattered Spiritual Self: Philosophical Reflections on Religious Trauma" Res Philosophica 95: 505-530.

---. 2019. "That We May be Whole: Doing Philosophy of Religion with the Whole Self." In The Lost Sheep in Philosophy of Religion: New Perspectives on Disability, Gender, Race, and Animals, edited by Blake Hereth and Kevin Timpe. Routledge: 55-76.

Quinn, Philip L. 1978. Divine Commands and Moral Requirements. Clarendon Press.

---. 2010. "Sin and Original Sin.” In A Companion to Philosophy of Religion (Second Edition), edited by Charles Taliaferro, Paul Draper, and Philip L. Quinn. Blackwell: 614-621. 
Rausche, Benedikt. 2012. "The Relevance of Purity in Second Temple Judaism according to Ezra-Nehemiah." In Purity and the Forming of Religious Traditions in the Ancient Mediterranean World and Ancient Judaism, edited by Christophe Nihan and Christian Frevel. Brill: 457-475

Rawls, John. 2009 (1942). "A Brief Inquiry into the Meaning of Sin and Faith.” In John Rawls: A Brief Inquiry into the Meaning of Sin and Faith; with "On My Religion," edited by Thomas Nagel. Harvard University Press: 103-258.

Regev, Eyal. 2004. "Moral impurity and the temple in early Christianity in light of ancient Greek practice and Qumranic ideology." Harvard Theological Review 97 (4): 383-411. doi: $10.1017 / \mathrm{S} 0017816004000768$.

Rhoads, David M. 1992. "Social Criticism: Social Boundaries." In Mark and Method: New Approaches in Biblical Studies, edited by Janice Capel Anderson and Stephen D. Moore. Fortress Press: 135-161.

Roadevin, Cristina. 2019. "To Punish or to Forgive? Responding to Dirty Hand s in Politics." Theoria: A Journal of Social and Political Theory 66 (160): 122-142. DOI: $10.3167 /$ th.2019.6616007.

Roberts, Erin. 2014. "Reconsidering Hamartia as "Sin" in 1 Corinthians." Method and Theory in the Study of Religion 26: 340 -364. doi: 10.1163/15700682-12341315.

Schroeder, Mark. 2020. "Sins of Thought." Faith and Philosophy 37 (3): 1-21. doi: 10.37977/faithphil.2020.37.3.1.

Shea, Matthew. 2018. "Aquinas on God-Sanctioned Stealing." American Catholic Philosophical Quarterly 92 (2): 277-293 doi: 10.5840/acpq201831146.

Tennant, Frederick R. 1912. The Concept of Sin. Cambridge University Press.

Todd, Patrick. 2018. "Does God Have the Moral Standing to Blame?” Faith and Philosophy 35 (1): 33-55. doi: 10.5840/faithphil201811796.

Trigg, Roger. 1971. "Moral Conflict.” Mind 80 (317): 41-55.

van der Leeuw, Gerardus. 1938. Religion in Essence and Manifestation: A Study in Phenomenology. J.E. Turner (Trans.). George Allen \& Unwin.

Vicens, Leigh. 2018. "Sin and Implicit Bias." Journal of Analytic Theology 6: 100-111. doi: 10.12978/jat.2018-6.110407210818a.

Warmke, Brandon. 2017. "Divine Forgiveness I: Emotion and Punishment-Forbearance Theories.” Philosophy Compass 12 (e12440): 1-9 of 9. doi: 10.1111/phc3.12440.

Werrett, Ian. 2012. "The Evolution of Purity at Qumran.” In Purity and the Forming of Religious Traditions in the Ancient Mediterranean World and Ancient Judaism, edited by Christophe Nihan and Christian Frevel. Brill: 493-518. 
Wodak, Daniel. 2019. "Mere Formalities: Fictional Normativity and Normative Authority. Canadian Journal of Philosophy 49 (6): 828-850. doi: 10.1080/00455091.2018.1433795.

Wright, David P. 1991. "The Spectrum of Priestly Impurity." In Priesthood and Cult in Ancient Israel, edited by Gary A. Anderson and Saul M. Olyan. JSOT Press: 150-181. 